\title{
The Preventive Approach of Biocompounactives (2): A Review in Recent Advances in Common Fruits
}

\author{
Abdelkarim Guaâdaoui ${ }^{1, ~ *}$, Fatma Bouhtit ${ }^{2}$, Mounir Cherfi ${ }^{3}$, Abdellah Hamal ${ }^{1}$ \\ ${ }^{1}$ Department of Biology, Laboratory of Genetics \& Biotechnology (LGB), Faculty of Science - Oujda (FSO), University Mohammed Premier \\ (UMP) Oujda, Morocco \\ ${ }^{2}$ Department biological analysis, Laboratory for Analysis \& Quality Control (LACQ), University Mohammed Premier (UMP) Oujda, \\ Morocco \\ ${ }^{3}$ Medical Analysis Laboratory, Provincial Medical Center of Taourirt, Health Provincial Delegation of Taourirt, Ministry of Health, Morocco
}

Email address:

abdelkarim119@gmail.com (A. Guaâdaoui)

\section{To cite this article:}

Abdelkarim Guaâdaoui, Fatma Bouhtit, Mounir Cherfi, Abdellah Hamal. The Preventive Approach of Biocompounactives (2): A Review in Recent Advances in Common Fruits. International Journal of Nutrition and Food Sciences. Vol. 4, No. 2, 2015, pp. $189-207$. doi: 10.11648/j.ijnfs.20150402.21

\begin{abstract}
Biocompounactives contain chemicals that are found in small quantities in plants and certain foods (such as fruits, vegetables, nuts, oils and whole grains), they have actions in the body that can promote good health. The importance attached to benefits of food on health has never been so high before. All scientific studies confirm that a varied and balanced diet is factor of protection against cancer, cardiovascular disease (CVD), osteoporosis, diabetes, obesity and high cholesterol. In this second part of the review, we focus on studies that have been conducted on biocompounactives of common fruits, and opportunities that present bioactivity of these phytochemicals to prevent many chronic diseases. As well, we discuss some challenges that face the good investissment of biocompounactives, especially that related to bioavailability and bioefficacy, on the horizon to discuss the limits of experiments interpretation, mentioned here, in the third part of this review.
\end{abstract}

Keywords: Biocompounactives, Bioactive Compound, Phytochemicals, Functional Foods, Healthy Diet, Nutraceuticals, Fruits

\section{Introduction}

Biocompounactives are compounds which have the capability and the ability to interact with one or more component(s) of the living tissue by presenting a wide range of probable effects [1-3]. They are non-essential natural ingredients in, or derived from, plant, animal or marine sources, which have the ability to modulate biochemical, physiological and metabolic processes in the human body, while exerting beneficial effects beyond basic nutritional functions [4-6]. Generally, there is no difference in biological activity between the bioactive compounds derived from nature and synthetic products $[1,7]$.

Biocompounactives are experiencing a growing interest in wide range of applications: geo-medicine, plant science, modern pharmacology, agrochemicals, cosmetics, food industry, nano-bio-science... etc. This is a very promising area in full development, which has resulted in research works more and more numerous, designed to diversify the resources of bioactive compounds and improve their salvage pathways or synthesis $[1,2]$.

The importance attached to benefits of food on health has never been so high before [8], and if we except the genetic, ecological, physiological and botanical studies on food; research on the bioactive potential has experienced a veritable boom during the first decade of the twenty-first century, and took an accelerated rates over the beginning of the second decade, in a way that the research carried out during the past five years (2010-2014) on the majority of foods are equal or superior to the work done during all the previous decade (2000-2009) [3].

Biocompounactives contain chemicals that are found in small quantities in plants and certain foods (such as fruits, vegetables, nuts, oils and whole grains), they have actions in the body that can promote good health [9].

In this work, we continue on preventive approach of biocompounactives (part 2), and opportunities that present bioactivity of common fruits phytochemicals to prevent many chronic diseases. As well, we discuss some challenges that 
face the good investissment of biocompounactives.

\section{Food Biocompounactives Opportunities}

Noting that prevention is a more effective strategy than is treatment of chronic diseases [10]; the philosophy that food can be health promoting beyond its nutritional value is gaining acceptance within the public arena and among the scientific community as mounting research links diet/food components to disease prevention and treatment [11, 12].

Recent trends in the functional food market suggest that products with multiple health benefits become more and more popular [13] and dietary bioactive compounds have become another quality indication [14].

Over the past two decades, there has been a growing interest in the potential benefits of natural compounds on human health [15]. Interest in food composition has expanded beyond the nutrients to include bioactive compounds consumed in the traditional foods, which may help to prevent many chronic diseases that can coexist with malnutrition and undernutrition [16].

Biocompounactives are members of a large class of organic molecules that are widely distributed in the plant kingdom and, as such, are an integral part of the daily diet of humans [17].

Until 2013, it was estimated that more than 8000 phytochemicals have been identified in foods [18]. All these bioactive food components are mostly found in whole grains, fruits and vegetables [19, 20], but a large percentage still remain unknown and need to be identified before we can fully understand the health benefits of phytochemicals in whole foods [19].

The phytochemicals may be classified into carotenoids, phenolic compounds, alkaloids, nitrogen compounds and organosulfur compounds. But the most studied of these biocompounactives are phenolics and carotenoids [21].

Recent investigations show that food biomolecules that contribute to human health can be found particularly in glycosylated, esterified, thiolated or hydroxy forms. These bioactive compounds display their health benefits in metabolic activity associated with several diseases [20].

So the important role that biocompounactives can have in health is related to the intake of these compounds, which, in turn, strongly linked to the high consumption of fruits, vegetables and unrefined grains [22]. Indeed, several studies have shown that a high intake of fruits and vegetables reduces the risk of cardiovascular disease, certain cancers, and other chronic diseases [21, 23-26].

The concept of a healthy diet is considered an aspect of good and healthy practices. The observations in social behavior and archaeological discoveries lead researchers to notice that the longevity and healthy life, away from the high incidence of myocardial infarction and cancer, are caused by good habits of feeding [27].

The table (1) present bioactivities studied on some most common fruits, with their major biocompounactives.

Table 1. Bioactivity of dietary biocompounactives (Common Fruits case).

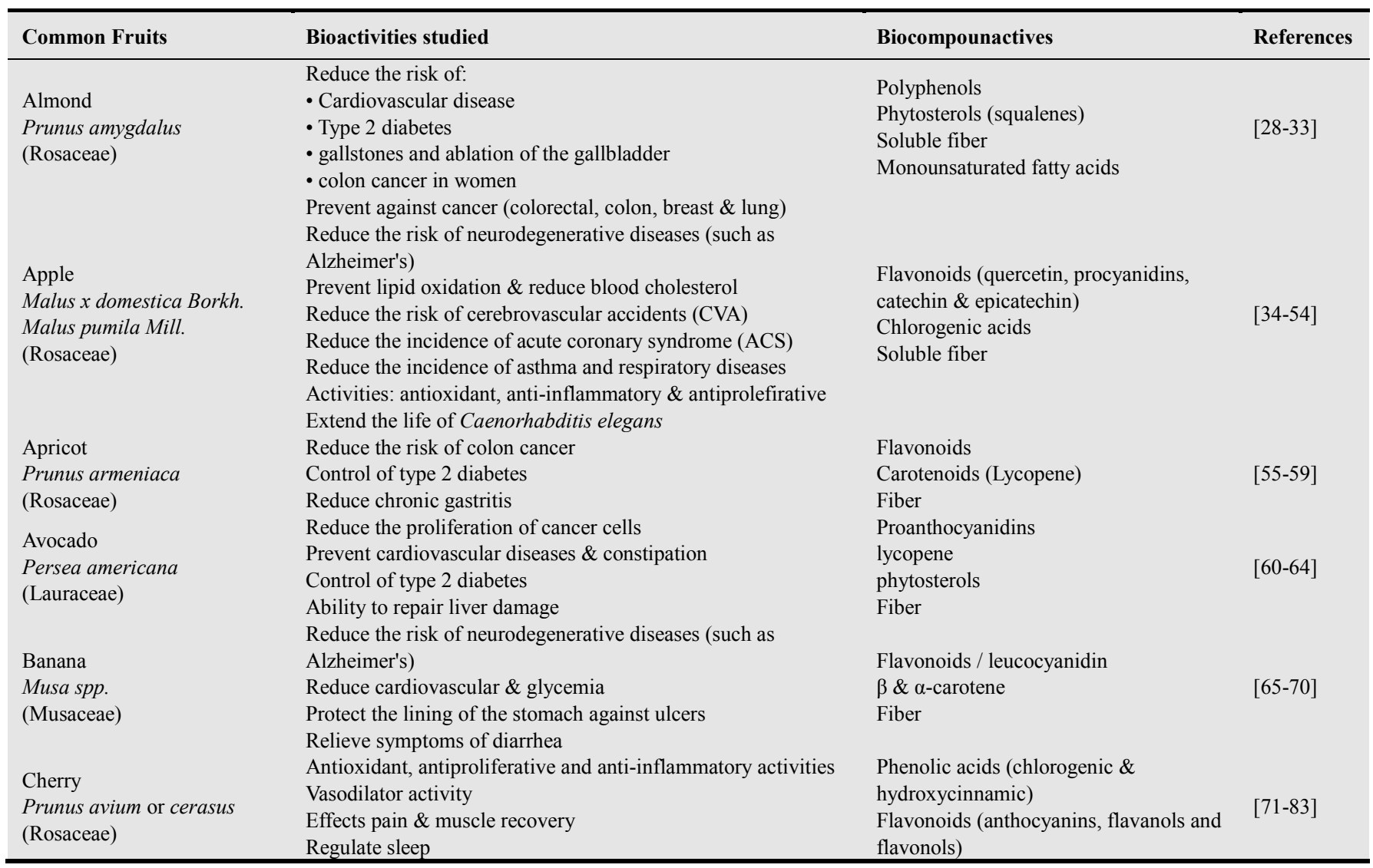




\begin{tabular}{|c|c|c|c|}
\hline Common Fruits & Bioactivities studied & Biocompounactives & References \\
\hline $\begin{array}{l}\text { Clementine } \\
\text { Tangerine } \\
\text { Citrus reticulata } \\
\text { (Rutaceae) }\end{array}$ & $\begin{array}{l}\text { Reduce the risk of certain cancers (lung, liver) } \\
\text { Cause apoptosis of cancer neuroblastoma cells } \\
\text { Antioxidant activities } \\
\text { Protect the integrity of neuronal cells } \\
\text { Anti-inflammatory potential in vitro } \\
\text { Prevent bone loss } \\
\text { Reduce blood cholesterol in animals }\end{array}$ & $\begin{array}{l}\text { Melatonin \& Serotonin } \\
\text { Flavonoids (isoflavones, hesperetin, } \\
\text { nobiletin \& tangeretin) } \\
\text { Limonoids (limonine \& nomiline) } \\
\text { Carotenoids ( } \beta \text {-cryptoxanthin) } \\
\text { Soluble fiber } \\
\text { Vitamin C }\end{array}$ & [84-92] \\
\hline $\begin{array}{l}\text { Date } \\
\text { Phoenix dactylifera } L \text {. } \\
\text { (Arecaceae) }\end{array}$ & $\begin{array}{l}\text { Anti-inflammatory } \\
\text { Antioxidant power } \\
\text { Reduce cholesterol } \\
\text { Normalize glucose and insulin levels } \\
\text { Prevent constipation }\end{array}$ & $\begin{array}{l}\text { Flavonoids (anthocyanins, luteolin, } \\
\text { quercetin \& rutin) } \\
\text { Phenolic acids (gallic, caffeic \& } \\
\text { coumaric) } \\
\text { Carotenoids ( } \beta \text {-carotene) } \\
\text { Fiber }\end{array}$ & [93-101] \\
\hline $\begin{array}{l}\text { Fig } \\
\text { Ficus carica } \\
\text { (Moraceae) }\end{array}$ & $\begin{array}{l}\text { Antioxidant activities } \\
\text { Antispasmodic \& antiplatelet activities } \\
\text { Potential against human melanoma } \\
\text { Normalizing cholesterol, glucose and insulin blood levels } \\
\text { Maintain proper intestinal function }\end{array}$ & $\begin{array}{l}\text { Flavonoids (anthocyanin) } \\
\text { Chlorogenic acid } \\
\text { Carotenoids (lycopene, lutein \& } \\
\beta \text {-carotene) } \\
\text { Coumarins } \\
\text { Fiber }\end{array}$ & [102-111] \\
\hline $\begin{array}{l}\text { Grapefruit \& Pomelo } \\
\text { Citrus grandis (L.) Osbeck } \\
\text { Citrus maxima (Burm.)Merr. } \\
\text { (Rutaceae) }\end{array}$ & $\begin{array}{l}\text { Induce apoptosis in cancer cells of the stomach } \\
\text { Reduce the risk of breast cancer } \\
\text { Inhibition of cell lines (Leukemia \& colon) in humans } \\
\text { Antihyperlipidemic \& antidiabetic properties } \\
\text { Antioxidant \& antiinflammatory activities } \\
\text { Effects on bone homeostasis }\end{array}$ & $\begin{array}{l}\text { Flavonoids (rhoifolin, cosmosiin, } \\
\text { naringin \& Hesperetin) } \\
\text { Carotenoids (lycopene \& } \beta \text {-carotene) } \\
\text { Coumarins (auraptene) } \\
\text { Limonoids (limonine) } \\
\text { Soluble fiber }\end{array}$ & [112-122] \\
\hline $\begin{array}{l}\text { Grapes } \\
\text { Vitis sp. } \\
\text { (Vitaceae) }\end{array}$ & $\begin{array}{l}\text { Prevent cardiovascular disease (CVD) } \\
\text { Remove carcinogenesis of breast cells / Reduce the } \\
\text { proliferation of cancer cells of the mammary gland } \\
\text { Induce apoptosis in colon cancer cell lines } \\
\text { Protective effect against cancer of the white blood cells } \\
\text { Prevent skin cancer } \\
\text { Protective effect against nephrotoxicity (in male rats) } \\
\text { Improve cognitive and immune functions } \\
\text { Prevent brain lipotoxicity (in rats) } \\
\text { Hepatoprotective effect } \\
\text { Activities: anti-inflammatory, anti-hypertensive, } \\
\text { anti-thrombotic, antiviral \& antibacterial }\end{array}$ & $\begin{array}{l}\text { Flavonoids: quercetin, myricetin, } \\
\text { kaempferol, catechin, epicatechin, } \\
\text { proanthocyanidins anthocyanins \& } \\
\text { Stilbene Trans-Resveratrol \& viniferin }\end{array}$ & [123-154] \\
\hline $\begin{array}{l}\text { Hazelnut } \\
\text { Corylus avellana } \\
\text { (Betulaceae) }\end{array}$ & $\begin{array}{l}\text { Antineoplastic agent } \\
\text { Reduce total cholesterol \& LDL cholesterol } \\
\text { Antibacterial activity }\end{array}$ & $\begin{array}{l}\text { Flavonoids } \\
\text { Tocopherols \& tocotrienols } \\
\text { Carotenoids ( } \beta \text {-carotene) } \\
\text { Tannins } \\
\text { Phytosterols ( } \beta \text {-cytosterol) }\end{array}$ & [155-159] \\
\hline $\begin{array}{l}\text { Kiwifruit } \\
\text { Actinidia deliciosa } \\
\text { (Actinidiaceae) }\end{array}$ & $\begin{array}{l}\text { Protection against oxidative DNA damage } \\
\text { Cardioprotective \& Hepatoprotective potential } \\
\text { Control diabetes (type 2) \& appetite } \\
\text { Help immune function } \\
\text { Treat chronic ulcers } \\
\text { Prevent constipation }\end{array}$ & $\begin{array}{l}\text { Flavan (epicatechin, catechin \& } \\
\text { procyanidins) } \\
\text { Flavonols (quercetin \& kaempferol) } \\
\text { Vitamin C } \\
\text { Fiber }\end{array}$ & [160-167] \\
\hline $\begin{array}{l}\text { Lemon } \\
\text { Citrus limon } \\
\text { Lime } \\
\text { Citrus aurantifolia } \\
\text { (Rutaceae) }\end{array}$ & $\begin{array}{l}\text { Inhibit the activity of HIV protease } \\
\text { Improve the immune system } \\
\text { Induce apoptosis of leukemic \& pancreatic cancer cells } \\
\text { Reduce the risk of the digestive tract cancers } \\
\text { Slow the growth of tumors and metastases (antiangiogenic } \\
\text { properties) } \\
\text { Reduce cholesterol. } \\
\text { Anti-inflammatory \& anti-coagulant }\end{array}$ & $\begin{array}{l}\text { Flavonoids (eriocitrin, hesperetin \& } \\
\text { nobiletin) } \\
\text { Limonoids (limonine, nomiline \& } \\
\text { obacunone) } \\
\text { Soluble fiber } \\
\text { Vitamin C }\end{array}$ & [168-178] \\
\hline $\begin{array}{l}\text { Loquat } \\
\text { Eriobotrya japonica } \\
\text { (Rosaceae) }\end{array}$ & $\begin{array}{l}\text { Anticancer \& antimetastatic } \\
\text { Antihyperglycemic } \\
\text { Hepatoprotective \& gastroprotective activities } \\
\text { Antioxidant \& anti-inflammatory activities }\end{array}$ & $\begin{array}{l}\text { Carotenoids }(\beta \text {-carotene \& } \\
\beta \text {-cryptoxanthin) } \\
\text { Phenolic acids } \\
\text { Fiber }\end{array}$ & [214-219] \\
\hline $\begin{array}{l}\text { Mango } \\
\text { Mangifera indica } \\
\text { (Anacardiaceae) }\end{array}$ & $\begin{array}{l}\text { Anticancer activity (prostate, colon, blood, breast) in vivo \& in } \\
\text { vitro } \\
\text { Repair and modulate DNA damage } \\
\text { Treat cognitive decline (in rats) } \\
\text { Antidiabetic \& Hypoglycemic effect }\end{array}$ & $\begin{array}{l}\text { Flavonoids (quercetin) } \\
\text { Mangiferine \& gallotannins } \\
\text { Carotenoids ( } \beta \text {-carotene, } \\
\beta \text {-cryptoxanthin \& violaxanthine) } \\
\text { Soluble fiber }\end{array}$ & [179-184] \\
\hline
\end{tabular}




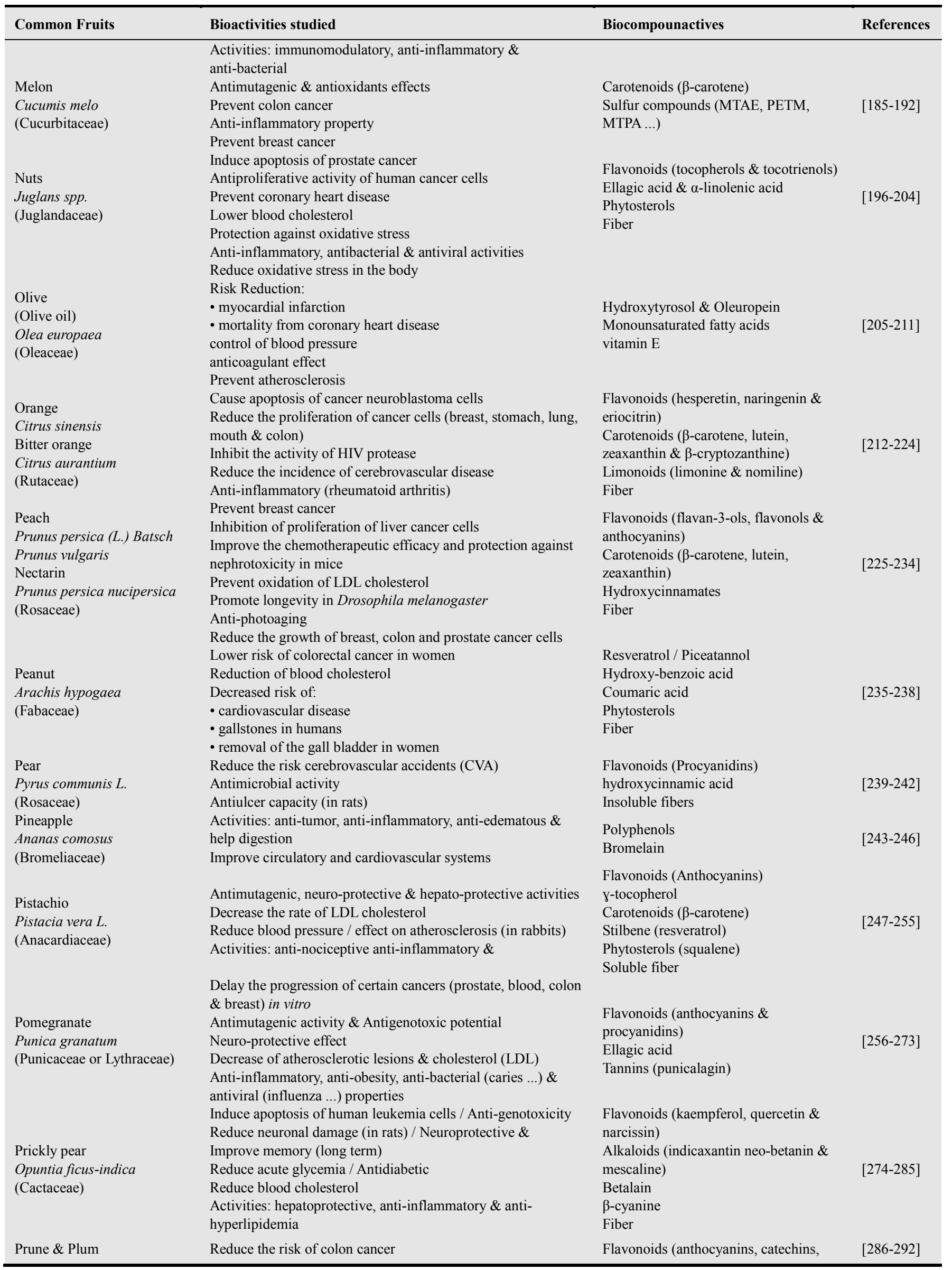




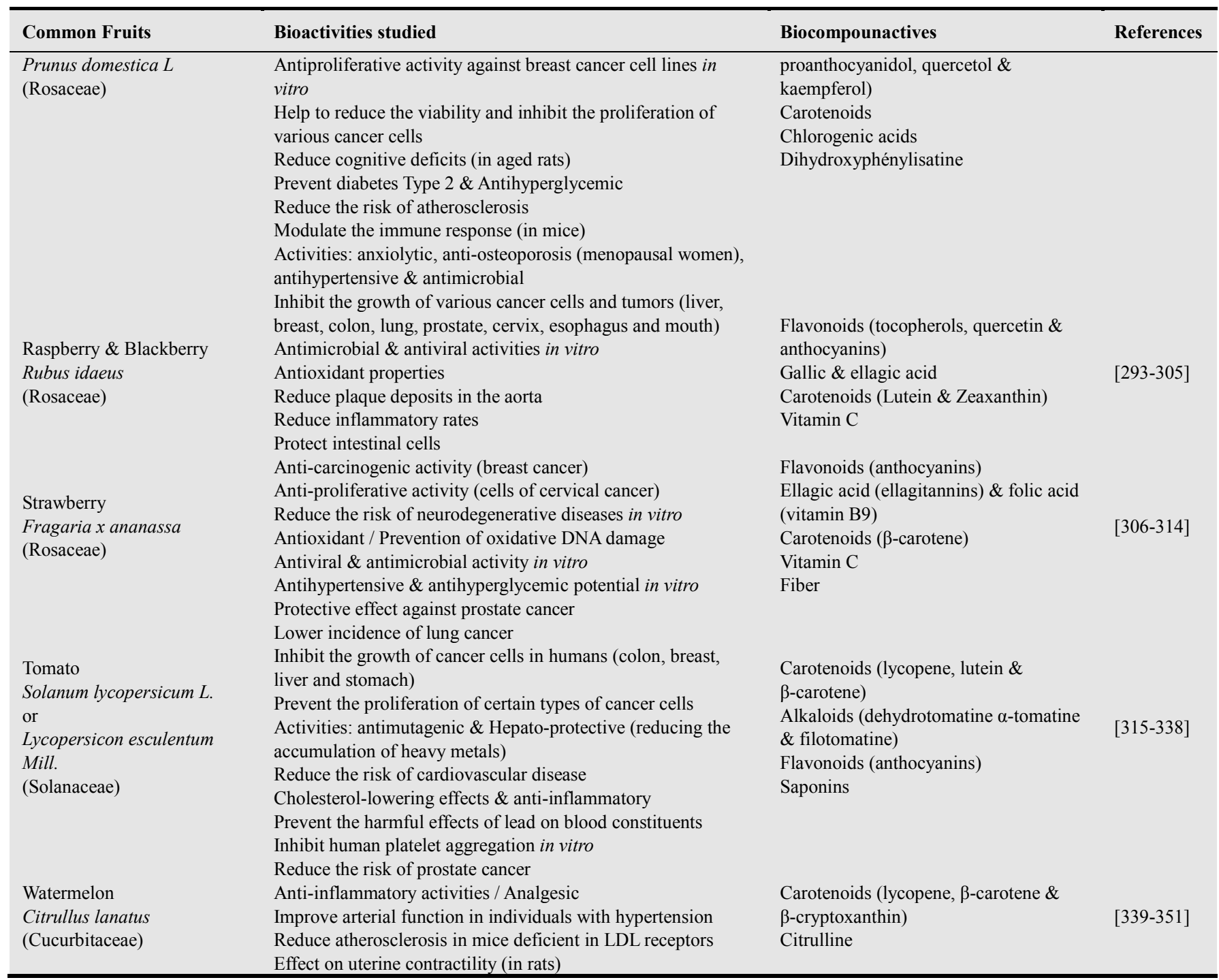

\section{Challenges of Biocompounactives Studies}

It is true that many phytochemicals such as polyphenols, carotenoids and organosulfur and nitrogen compounds, are thought to be involved in the prevention and treatment of many diseases, including some cancers, cardiovascular diseases, diabetes , degenerative diseases, inflammation, infections, psychotic diseases, ulcers, macular degeneration, ... etc. [352-354]. But, how manifest this mutual interaction between the different biocompounactives and biological systems? and what are the main factors that can affect the physicochemical properties of bioactive compounds in biological systems?

In the following, we will discuss the main challenges encountering the study of biocompounactives; knowing that the mechanisms of action, in general, are not well understood and often difficult to identify [355, 356], which makes determining the mode of action of biocompounactives, including natural products, central problem in chemical biology [357].

\subsection{Bioavailability \& Bioefficacy}

\subsubsection{Variation Factors of Bioavailability and Bioefficacy}

Bioactive compounds from a variety of sources (plant or animal) must be bioavailable to exert beneficial effects [358].

Bioavailability reflects the rate and extent to which a bioactive compound is absorbed and becomes available at the site of action in a biological system. This is a complex process involving several steps: liberation, absorption, distribution, metabolism and elimination phases (LADME). This process, of course, can vary considerably between individuals, and this variation depends on several key factors, including diet, genetic inheritance, composition and activity of the intestinal microbiota [359, 360].

In addition to the variations between individuals; many factors may be involved in the same person and affect the quality of bioavailability and consequently affect the bio-efficacy. Among these factors are briefly cited $[2,16$, 359-361]:

o bioaccessibility: This is the fraction of a compound that is released from the matrix (food) in the gastrointestinal 
lumen and thus made available for intestinal absorption.

o Molecular structure and isomeric configuration of biocompounactives: High molecular weight compounds do not pass through the intestinal cells unless they are first broken (glycosylated flavonoids, for example) and a different stereochemistry has a bioavailability and bioefficacy different (for example cis-lycopene more bioavailable comparably to the all-trans isomer). Slight variations in chemical structure result in extreme variations in biological activities.

o Transport mechanisms: Since many biocompounactives have no optimal physicochemical properties required for passive diffusion, transmembrane transporters are necessary to improve their permeability. The activity of different transporters affects biocompounactives by several different mechanisms, such as limiting the absorption, facilitating the elimination and limiting distribution to target tissues. This limitation may be due to the selectivity and affinity of intestinal transport systems towards different biocompounactives or competition for transport by transporters (hypothesis of competitive inhibition).

o Metabolism: Once the bioactive molecule is input in an enterocyte, it can be submitted to metabolism by enzymes of Phase I and/or Phase II, resulting by molecular forms that are different from origins constituents. In a quite similar way, many other phytochemicals are highly metabolized by the intestinal microbiota before absorption; and again, the compounds in the systemic circulation to which the cells are exposed are different from those obtained directly from the plant.

It is only when the circulating forms of a bioactive molecule or a food product is known; a more complete view on the bioavailability, and possible correlation of bioefficacy, can be obtained. For drugs, it is a requirement when conducting bioavailability studies; and this type of approach can also be translated to nutritional research [360].

\subsubsection{Improvement Approaches for Bioavailability and Bioefficacy}

Face to this difficult course for the bioefficacy; several approaches have been evaluated to improve the bioaccessibility and bioavailability of bioactive ingredients and drugs. These sometimes include simple things, like the treatment and processing of the food matrix. For tomatoes, for example, lycopene has proved a better bioavailability when the tomatoes are cooked or mixed with a small amount of fat. Blood levels of lycopene may increase almost three times more than the consumption of fresh tomatoes [362-364]. But most approaches call technology by molecular changes to improve the solubility or absorption site of bioactive molecules [365].

Several chemical efforts aimed at improving bioavailability have led to the synthesis of derivatives or conjugates of natural molecules and the preparation of novel formulations and combinations having improved physicochemical properties. We can give as an example, the modification of a natural alkaloid (Huperzine A) in a semi-synthetic bioactive compound (ZT-1), whose the new design has improved the bioavailability and reduce the toxicity [366]. Molecular modeling of some coumarins is another example of combination of crystallographic and biological data, in order to design compounds which possess better bioavailability [367].

For the same purpose, and in addition to responding to the challenges of the sensitivity of biocompounactives, several technologies have been developed, including the encapsulation of bioactive molecules (water-soluble or fat-soluble) in different forms (microcapsule, micelle, uni/multilamellar vesicle ...) [368, 369].

Oehlke K. et al. (2014) cited the growing interest of nanoscale materials (nanotechnology) designed as delivery systems for organic and inorganic materials in order to overcome the problems associated with the low bioavailability of many bioactive compounds. The mechanisms leading to better bioavailability, according to the authors, are based on (i) improved solubility of the bioactive compounds in gastrointestinal conditions, (ii) protection of bioactive compounds from chemical conditions in the gastrointestinal tract, (iii) controlled release in the gastrointestinal tract, or (iv) improved transfer through the intestinal wall [370].

A final biotechnological method that can be mentioned in this context is that of biocatalysts. Some bacteria, such as Klebsiella pneumoniae, Xanthomonas campestris and Lactobacillus delbrueckii, are known to produce exopolysaccharides that are excreted into the culture medium. These bacteria are expected to convert exogenous lipophilic food ingredients in their glycosides soluble in water. In tocopherols, for example, this characteristic reaction (glycosylation), has converted the $\alpha$ - and $\delta$-tocopherols by two biocatalysts glycosides tocopheryl, thus improving bioavailability and pharmacological properties as food additives with an effective antiallergic activity [371, 372].

\subsection{Limits of Experiments Interpretation}

The diversity and complexity of biocompounactives, alone, make the study of all these compounds and understanding their mechanisms of action a very difficult mission. While many critics emerge to highlight, and draw attention to, some details relating to the study of bioactive compounds.

Indeed, there are important limitations that must be considered before interpreting an experiment to prove the effectiveness of a product. Traka M.H. and Mithen R.F. (2011); underlining the need for human intervention studies to provide high quality data for health of bioactive components; have criticized the data types used to support activities of some phytochemicals that promote health, including limits of observational and epidemiological studies, and research through the use of cell lines and animal models [361].

So, the major problem for evaluating the biological activity is that these studies present many challenges in the interpretation and extrapolation to humans. But despite all these challenges, various studies have very important benefits, and that is what we will discuss in the third and the last part of 
this review, as already promised in our first study about this approach [3].

In all cases, significant efforts are needed to increase the number of clinical studies are still limited, and therefore, provide compelling evidence of the benefits of bioactive compounds in humans [373].

\section{Conclusion}

All scientific studies confirm that a varied and balanced diet, with minimal physical activity, is factor of protection against cancer, cardiovascular disease, osteoporosis, diabetes, obesity and high cholesterol. True that these diseases do not depend exclusively on food, they are also influenced by genetic factors, but if we cannot choose our ancestors, we can choose our food and organize our lifestyle [3, 374]!

In the first part of this review, we have presented opportunities that contain some most common vegetables and legumes, with discussion of challenges relating to (i) radical reversal dietary habits and how to provide science to the public, (ii) methods of food processing that may affect the content, activity and bioavailability of biocompounactives in foods, and (iii) allergic reactions of some food-borne phytochemicals that are responsible for a variety of symptoms and disorders in human body [3].

In this review (part 2) we focused on studies that have been conducted on biocompounactives of common fruits, and opportunities that present bioactivity of these phytochemicals to prevent many chronic diseases. As well, emphasis is placed on some challenges that face the good investissment of biocompounactives, especially bioavailability and bioefficacy; with discussion of some improvement approaches for these factors, like (i) molecular modeling, (ii) nanotechnologies and (iii) biocatalysts.

In the third, and last part of this study, we continue on preventive approach of biocompounactives that contain cereals and some foods of animal origin, with discussion of other opportunities and challenges facing this approach, especially those concerning the revelation of bioactivities using observational and epidemiological studies, and research through the use of cell lines and animal models as mentioned above.

\section{Acknowledgements}

Abdelkarim G. thanks Professors Abderrahim BOUALI and Abderrahim ZIYYAT for directions and observations they provided during the preparation of this research.

\section{References}

[1] Abdelkarim $\mathrm{G}$ et al.; What is a bioactive compound? A combined definition for a preliminary consensus. International Journal of Nutrition and Food Sciences, 2014, 3(3): 174-179.

[2] Abdelkarim $\mathrm{G}$ et al.; Betalains, Polyacetylenes and Tocols as Biocompounactives: A Concise Review for Enriching the
Bioactivity Concept. International Journal of Nutrition and Food Sciences, 2014, 3(4): 230-237.

[3] Abdelkarim $\mathrm{G}$ et al.; The Preventive Approach of Biocompounactives (1): A Review in Recent Advances in Common Vegetables and Legumes. International Journal of Nutrition and Food Sciences. 2015, 4(1): 89-102.

[4] Kris-Etherton PM et al. ; Bioactive compounds in foods: their role in the prevention of cardiovascular disease and cancer. American Journal of Medicine, 2002, 113(Suppl 9B): 71S-88S.

[5] Tejasari D; Evaluation of ginger (Zingiber officinale Roscoe) bioactive compounds in increasing the ratio of T-cell surface molecules of $\mathrm{CD} 3+\mathrm{CD} 4+: \mathrm{CD} 3+\mathrm{CD} 8+$ In-Vitro. Malysian Journal of Nutrition, 2007, 13(2): 161-170.

[6] Denny A and Buttriss J; Plant foods and health: focus on plant bioactives. Synthesis Report No.4, European Food Information Resource (EuroFIR). British Nutrition Foundation. London, 2008: 1-64.

[7] Biesalski HK et al.; Bioactive compounds: Safety and efficacy. Nutrition, 2009, 25(11-12): 1206-1211.

[8] Bonaccio $\mathrm{M}$ et al.; The Mediterranean diet: The reasons for a success. Thrombosis Research, 2012, 129: 401-404.

[9] Anonymous ; Waste: A source of bioactive compounds, Biotechnology Journal, 2008, 3(7) : 1.

[10] Liu RH; Health benefits of fruits and vegetables are from additive and synergistic combination of phytochemicals. The American Journal of Clinical Nutrition, 2003, 78(3S): $517 \mathrm{~S}-520 \mathrm{~S}$.

[11] Bonaccio $\mathrm{M}$ et al.; The Mediterranean diet: The reasons for a success. Thrombosis Research, 2012, 129: 401-404.

[12] Abby B and Cynthia AT; Position of the American Dietetic Association: phytochemicals and functional foods. Journal of the American Dietetic Association, 1995, 95(4): 493-496.

[13] Day L et al.; Incorporation of functional ingredients into foods. Trends in Food Science and Technology, 2009, 20(9): 388-395.

[14] Park YS et al.; Analytical determination of bioactive compounds as an indication of fruit quality. Journal of AOAC International, 2012, 95(6): 1725-1732.

[15] Teratanavat R and Hooker NH ; Consumer Valuations and Preference Heterogeneity for a Novel Functional Food. Journal of Food Science, 2006, 71(7): S533-S541.

[16] Biesalski HK et al.; Bioactive compounds: Definition and assessment of activity. Nutrition, 2009, 25(11-12) : 1202-1205.

[17] Pandey KB and Rizvi SI: Plant polyphenols as dietary antioxidants in human health and disease. Oxidative Medicine and Cellular Longevity, 2009, 2(5): 270-278.

[18] Liu RH; Potential Synergy of Phytochemicals in Cancer Prevention: Mechanism of Action. Journal of Nutrition, 2004, 134(12S): 3479S-3485S.

[19] Sreeramulu D et al.; Natural Antioxidant Activity of Commonly Consumed Plant Foods in India: Effect of Domestic Processing. Oxidative Medicine and Cellular Longevity, 2013 (2013): 1-12.

[20] Klotzbach-Shimomura K; Herbs and health: safety and effectiveness. Journal of Nutrition Education, 2001, 33 : 354-355. 
[21] Willett WC; Balancing life-style and genomics research for disease prevention. Science, 2002, 296: 695-698.

[22] Collier R; Japanese longevity. Canadian Medical Association Journal, 2010, 182(12) : E579.

[23] Kris-Etherton PM et al.; Recent discoveries in inclusive food-based approaches and dietary patterns for reduction in risk for cardiovascular disease. Current Opinion in Lipidology, 2002, 13(4): 397-407.

[24] Bazzano LA et al.; Dietary intake of fruits and vegetables and risk of cardiovascular disease. Current Atherosclerosis Reports, 2003, 5(6): 492-9.

[25] Lampe JW; Health effects of vegetables and fruit: assessing mechanisms of action in human experimental studies. The American Journal of Clinical Nutrition, 1999, 3(70): 475S-90S.

[26] Harding AH et al.; Plasma vitamin $\mathrm{C}$ level, fruit and vegetable consumption, and the risk of new-onset type 2 diabetes mellitus: the European prospective investigation of cancer--Norfolk prospective study. Archives of Internal Medicine, 2008,168: $1493-9$.

[27] Schauss AG; Emerging Knowledge of the Bioactivity of Foods in the Diets of Indigenous North Americans (Chapter 5). Bioactive Foods in Promoting Health: Fruits and Vegetables, Elsevier Inc., 2010: 71-84.

[28] Maria $\mathrm{M}$ et al., Almond (Prunus dulcis (Mill.)) D.A. Webb) skins as a potential source of bioactive polyphenols, Journal of agricultural and food chemistry, 2007, 55(21) : 8498-8507.

[29] João CMB et al.; Antioxidant activity and bioactive compounds of ten Portuguese regional and commercial almond cultivars. Food and Chemical Toxicology, 2008, 46(6): 2230 - 2235.

[30] Anonymous; Almond as a functional food and source of bioactive nutrients, Nutrition Research Newsletter, 2009, 28(1): 1 .

[31] Sathe SK et al. ; Fatty acid composition of California grown almonds, Journal of food science, 2008, 73(9): C607-C614.

[32] Tsai CJ et al. ; Frequent nut consumption and decreased risk of cholecystectomy in women. American Journal of Clinical Nutrition, 2004, 80: 76-81.

[33] Jenkins DJ et al. ; Dose response of almonds on coronary heart disease risk factors: blood lipids, oxidized low-density lipoproteins, homocysteine, and pulmonary nitric oxide: a randomized, controlled, crossover trial. 2002, 106: 1327-32.

[34] Thilakarathna SH et al.; Apple peel bioactive rich extracts effectively inhibit in vitro human LDL cholesterol oxidation. Food chemistry, 2013, 138(1): 463 - 470.

[35] Tadahiro $\mathrm{S}$ et al.; Procyanidins from Apples (Malus pumila Mill.) Extend the Lifespan of Caenorhabditis elegans. Planta Medica, 2010, 77(2): 122 - 127.

[36] Sun-Waterhouse D et al. ; Juices, Fibres and Skin Waste Extracts from White, Pink or Red-Fleshed Apple Genotypes as Potential Food Ingredients; Food and Bioprocess Technology, 2013, 6(2): 377 - 390.

[37] Yang J et al.; Hepatoprotective effects of apple polyphenols on CCl4-induced acute liver damage in mice. Journal of agricultural and food chemistry, 2010, 58(10): 6525-6531.
[38] Yang J and Liu RH ; Synergistic effect of apple extracts and quercetin 3-beta-d-glucoside combination on antiproliferative activity in MCF-7 human breast cancer cells in vitro. Journal of agricultural and food chemistry, 2009, 57(18): 8581-8586.

[39] Zessner $\mathrm{H}$ et al. ; Fractionation of polyphenol-enriched apple juice extracts to identify constituents with cancer chemopreventive potential. Molecular Nutrition \& Food Research, 2008, 52(Suppl 1): S28-S44.

[40] Veeriah S et al. ; Apple -flavonoids inhibit growth of HT29 human colon cancer cells and modulate expression of genes involved in the biotransformation of xenobiotics. Molecular Carcinogenesis, 2006, 45(3): 164-174.

[41] Veeriah S et al. ; Apple polyphenols modulate expression of selected genes related to toxicological defence and stress response in human colon adenoma cells. International Journal of Cancer, 2008, 122(12): 2647-2655.

[42] Setorki $\mathrm{M}$ et al.; Effects of apple juice on risk factors of lipid profile, inflammation and coagulation, endothelial markers and atherosclerotic lesions in high cholesterolemic rabbits. Lipids in Health and Disease, 2009, 8: 39.

[43] Auclair S et al.; Apple polyphenols and fibers attenuate atherosclerosis in apolipoprotein E-deficient mice. Journal of agricultural and food chemistry, 2008, 56(14): 5558-63.

[44] Lam CK et al.; Apple polyphenols inhibit plasma CETP activity and reduce the ratio of non-HDL to HDL cholesterol. Molecular Nutrition \& Food Research, 2008, 52(8): 950-958.

[45] Nadeem A et al.; Oxidant-antioxidant imbalance in asthma: scientific evidence, epidemiological data and possible therapeutic options. Therapeutic Advances in Respiratory Disease, 2008, 2(4):215-235.

[46] Litonjua AA; Dietary factors and the development of asthma Immunology And Allergy Clinics of North America, 2008, 28(3): 603-629.

[47] Jedrychowski W et al.; Case-control study on beneficial effect of regular consumption of apples on colorectal cancer risk in a population with relatively low intake of fruits and vegetables. European Journal of Cancer Prevention, 2010, 19(1): 42-47.

[48] Koch TC et al.; Prevention of colon carcinogenesis by apple juice in vivo: impact of juice constituents and obesity. Molecular Nutrition \& Food Research, 2009, 53(10): 1289-1302.

[49] Schrenk D; Apple Juice and Intestinal Health. Molecular Nutrition \& Food Research., 2009, 53(10): 1209.

[50] Gerhauser C; Cancer chemopreventive potential of apples, apple juice, and apple components. Planta Medica, 2008, 74:1608-1624.

[51] He X and Liu RH. Phytochemicals of apple peels: isolation, structure elucidation, and their antiproliferative and antioxidant activities. Journal of Agricultural and Food Chemistry, 2008, 56: 9905-9910.

[52] Kujawska $M$ et al.; Cloudy apple juice protects against chemical-induced oxidative stress in rat. European Journal of Nutrition, 2010, 12: 24-35

[53] Teller $\mathrm{N}$ et al.; Apple procyanidins affect several members of the ErbB receptor tyrosine kinase family in vitro; Food \& Function, 2013, 4(5): 689 - 697. 
[54] Hooshmand S et al. ; Comparative effects of dried plum and dried apple on bone in postmenopausal women. British Journal of Nutrition, 2011, 106(6): 923-930.

[55] Enomoto S et al.; Inhibitory effects of Japanese apricot (Prunus mume Siebold et Zucc.; Ume) on Helicobacter pylori-related chronic gastritis. European Journal of Clinical Nutrition, 2010, $64: 714-719$.

[56] Sochor $\mathrm{J}$ et al. Content of Phenolic Compounds and Antioxidant Capacity in Fruits of Apricot Genotypes. Molecules, 2010, 15: 6285-6305.

[57] Hussain PR et al.; Bioactive compounds and antioxidant activity of gamma irradiated sun dried apricots (Prunus armeniaca L.); Journal of Food Composition and Analysis, 2013, 30(2): 59-60.

[58] Gholamhossein D et al.; Influence of Putrescine Application on Storability, Postharvest Quality and Antioxidant Activity of Two Iranian Apricot (Prunus armeniaca L.) Cultivars; Notulae Scientia Biologicae, 2013, 5(2) : 212-219.

[59] Oluranti E et al.; Phenolic and Carotenoid Composition of Canned Peaches (Prunus persica) and Apricots (Prunus armeniaca) as Affected by Variety and Peeling; Food Research International, 2013, 54(1): 448-455.

[60] Lucía P and al.; Fatty acids, sterols, and antioxidant activity in minimally processed avocados during refrigerated storage, Journal of agricultural and food chemistry, 2009, 57(8): 3204.

[61] Daniel AJV and Carmen HB, Stability of avocado paste carotenoids as affected by high hydrostatic pressure processing and storage, Innovative Food Science \& Emerging Technologies, 2012, 16: 121.

[62] Lu QY et al. ; Inhibition of prostate cancer cell growth by an avocado extract: role of lipid-soluble bioactive substances. The Journal of Nutritional Biochemistry, 2005, 16(1): 23-30.

[63] Unlu NZ et al. ; Carotenoid absorption from salad and salsa by humans is enhanced by the addition of avocado or avocado oil. Journal of Nutrition, 2005, 135(3): 431-436.

[64] Heber D; Inhibition of prostate cancer cell growth by an avocado extract: role of lipid-soluble bioactive substances. Clinical Oncology Week, 2005: 235p.

[65] Bonnet B et al. ; Effect of physiological harvest stages on the composition of bioactive compounds in Cavendish bananas, Journal of Zhejiang University Science B, 2013, 14(4): 270 278.

[66] Rabbani GH et al. ; Green banana and pectin improve small intestinal permeability and reduce fluid loss in Bangladeshi children with persistent diarrhea. Digestive Diseases and Sciences, 2004, 49(3): 475-484.

[67] Ble-Castillo JL et al. ; Effects of native banana starch supplementation on body weight and insulin sensitivity in obese type 2 diabetics. International Journal of Environmental Research and Public Health, 2010, 7: 1953-1962.

[68] Bennett RN et al. ; Phenolics and antioxidant properties of fruit pulp and cell wall fractions of postharvest banana (Musa acuminata Juss.) cultivars. Journal of agricultural and food chemistry, 2010, 58: 7991-8003.

[69] Rios de Souza V et al. ; Determination of bioactive compounds, antioxidant activity and chemical composition of Cerrado
Brazilian fruits, Food Chemistry, 2012, 134(1): 381.

[70] Heo HJ et al.; Effects of banana, orange, and apple on oxidative stress-induced neurotoxicity in PC12 cells; Journal of Food Science., 2008, 73(2): H28-H32.

[71] Ana Teresa $\mathrm{S}$ et al. ; Identification of bioactive response in traditional cherries from Portugal, Food Chemistry, 2011, 125(2): 318-325.

[72] Manuel JS et al.; Physicochemical and bioactive properties evolution during ripening of 'Ambrunés' sweet cherry cultivar, LWT - Food Science and Technology, 2011, 44(1): 199 - 205.

[73] Istvan B et al.; Isolation and analysis of bioactive constituents of sour cherry (Prunus cerasus) seed kernel: an emerging functional food, Journal of medicinal food, 2010, 13(4): 905 910.

[74] Pigeon WR et al.; Effects of a tart cherry juice beverage on the sleep of older adults with insomnia: a pilot study. Journal of Medicinal Food., 2010, 13(3): 579-583.

[75] Jakobeka L et al.; Flavonol and phenolic acid composition of sweet cherries (cv. Lapins) produced on six different vegetative rootstocks, Scientia Horticulturae, 2009, 123(1): 23-28.

[76] Kim DO et al.; Sweet and sour cherry phenolics and their protective effects on neuronal cells. Journal of agricultural and food chemistry, 2005, 53: 9921-9927.

[77] Mulabagal V et al.; Anthocyanin content, lipid peroxidation and cyclooxygenase enzyme inhibitory activities of sweet and sour cherries. Journal of agricultural and food chemistry, 2009, 57(4): 1239-1246.

[78] Kuehl KS et al.; Efficacy of tart cherry juice in reducing muscle pain during running: a randomized controlled trial. J Int Soc Sports Nutr, 2010, 7: 17.

[79] Bobe $G$ et al.; Dietary anthocyanin-rich tart cherry extract inhibits intestinal tumorigenesis in APC(Min) mice fed suboptimal levels of sulindac. Journal of agricultural and food chemistry, 2006, 54(25): 9322-9328.

[80] Schmitz-Eiberger MA and Blanke MM; Bioactive components in forced sweet cherry fruit (Prunus avium L.), antioxidative capacity and allergenic potential as dependent on cultivation under cover, Food Science and Technology, 2012, 46(2): 388.

[81] McCune LM et al.; Cherries and health: a review, Critical reviews in food science and nutrition, 2011, 51(1): 1-12.

[82] Gianna F et al.; Cherry antioxidants: from farm to table, Molecules (Basel, Switzerland), 2010, 15(10): 6993 - 7005.

[83] Hegedűs A et al.; Fruit antioxidant capacity and self-incompatibility genotype of Ukrainian sweet cherry (Prunus avium L.) cultivars highlight their breeding prospects. Euphytica, 2013, 191(1): 153-164.

[84] Wolfgang S et al.; Polymethoxylated flavones, flavanone glycosides, carotenoids, and antioxidants in different cultivation types of tangerines (Citrus reticulata Blanco $\mathrm{cv}$. Sainampueng) from Northern Thailand. Journal of agricultural and food chemistry, 2010, 58(10): 6069.

[85] Murthy $\mathrm{C}$ et al.; Citrus limonin and its glucoside inhibit colon adenocarcinoma cell proliferation through apoptosis. Journal of agricultural and food chemistry, 2011, 59(6): 2314. 
[86] Sawsen $\mathrm{S}$ et al.; Phenolic composition, organic acids, sugars, vitamin $\mathrm{C}$ and antioxidant activity in the juice of two new triploid late-season mandarins. Food Research International, 2012, 49(1): 462 - 468.

[87] Abeysinghe DC et al.; Bioactive compounds and antioxidant capacities in different edible tissues of citrus fruit of four species. Food Chemistry, 2007, 104(4): 1338-1344.

[88] Su-Chen $\mathrm{H}$ and Chih-Cheng L; Investigation of heat treating conditions for enhancing the anti-inflammatory activity of citrus fruit (Citrus reticulata) peels. Journal of agricultural and food chemistry, 2008, 56(17): 7976-7982.

[89] Cui Y et al.; Anti-neuroinflammatory Activity of Nobiletin on Suppression of Microglial Activation. Biol Pharm Bull, 2010, 33: $1814-1821$

[90] Qizhen D and Hui C; The methoxyflavones in Citrus reticulata Blanco cv. ponkan and their antiproliferative activity against cancer cells. Food Chemistry, 2010, 119(2): 567-572.

[91] Goulas V and Manganaris GA; Exploring the phytochemical content and the antioxidant potential of Citrus fruits grown in Cyprus. Food Chemistry, 2012, 131(1): 39-47.

[92] Cristina RA et al.; Effect of X-ray irradiation on nutritional and antifungal bioactive compounds of 'Clemenules' clementine mandarins. Postharvest Biology and Technology, 2012, 68: 47 53.

[93] Benmeddourand $\mathrm{Z}$ et al.; Phenolic composition and antioxidant capacities of ten Algerian date (Phoenix dactylifera L.) cultivars: A comparative study. Journal of Functional Foods, 2013, 5(1): 346-354.

[94] Ahmed $\mathbf{J}$ et al.; Isolation and characterization of insoluble date (Phoenix dactylifera L.) fibers. LWT - Food Science and Technology, 2013, 50(2): 414-419.

[95] Chuan-Rui Z et al.; Antioxidant and Anti-inflammatory Assays Confirm Bioactive Compounds in Ajwa Date Fruit. Journal of Agricultural and Food Chemistry, 2013, 61(24): 5834-5840.

[96] Fatma A et al.; Effect of concentration temperature on some bioactive compounds and antioxidant proprieties of date syrup. Food Science and Technology International, 2013, 19(4): 323 333.

[97] Taha HS et al.; A new concept for production and scaling up of bioactive compounds from Egyptian date palm (Zaghlool) cultivar using bioreactor, Emirates Journal of Food and Agriculture, 2012, 24(5): 425.

[98] Al Farsi MA and Lee CY; Nutritional and functional properties of dates: a review. Critical Reviews in Food Science and Nutrition, 2008, 48: 877-887.

[99] Kchaou W et al.; Effects of extraction solvents on phenolic contents and antioxidant activities of Tunisian date varieties (Phoenix dactylifera L.). Industrial Crops and Products, 2013, 45: 262-269.

[100] Al-Farsi MA and Lee CY; Usage of Date (Phoenix dactylifera L.) Seeds in Human Health and Animal Feed. Nuts and Seeds in Health and Disease Prevention, 2011: 447-452.

[101] El-Hadrami A et al. ; Secondary Metabolites of Date Palm, 2011: 653-674.

[102] Alasalvar C and Shahidi F; Functional Characteristics of Dried Figs (Dried Fruits: Phytochemicals and Health Effects), 2012:
284-299.

[103] Vallejo F et al.; Phenolic compound content of fresh and dried figs (Ficus carica L.); Food Chemistry, 2011, 130(3): 485.

[104] Waheed S and Siddique N; Evaluation of dietary status with respect to trace element intake from dry fruits consumed in Pakistan: a study using instrumental neutron activation analysis. International Journal of Food Sciences and Nutrition, 2009, 60: 333-343.

[105] Giovanna N et al.; Ficus carica: Research and development of a dry extract, Nutrafoods, 2010, 9(3): 27 - 30.

[106] Oliveira A et al.; Further insights into Ficus carica latex metabolome. Planta Medica, 2010, 76(12): P336.

[107] Sezai E et al., Color and antioxidant characteristics of some fresh fig (Ficus carica L.) genotypes from northeastern Turkey. Plant foods for human nutrition (Dordrecht, Netherlands), 2012, 67(3): 271 - 276.

[108] Hassan GA et al.; Ethnopharmacological studies on antispasmodic and antiplatelet activities of Ficus carica. Journal of ethnopharmacology, 2008, 119(1): 1 - 5.

[109] Conforti F et al.; Evaluation of phototoxic potential of aerial components of the fig tree against human melanoma. Cell Proliferation, 2012, 45(3): 279 - 285.

[110] Salim O et al.; Antioxidant activities of some dried fruits consumed in Algeria. LWT - Food Science and Technology, 2012, 49(2): 329

[111] Lori Z; Figure figs into a healthy diet. Environmental Nutrition, 2011, 34(7):. 8 .

[112] Mäkynen, $\mathrm{K}$ et al.; Cultivar variations in antioxidant and antihyperlipidemic properties of pomelo pulp (Citrus grandis [L.] Osbeck) in Thailand; Food chemistry, 2013, 139(1-4): 735.

[113] Raveh E et al.; Influence of rootstock and scion on antioxidant capacity of juice from new pomelo and mandarin varieties; Journal of the Science of Food and Agriculture, 2009, 89(11): $1825-1830$.

[114] Kongkachuichai R et al.; Carotenoid, flavonoid profiles and dietary fiber contents of fruits commonly consumed in Thailand; International Journal of Food Sciences and Nutrition, 2010, 61(5): 536 - 536.

[115] Xiao-Qi Z et al.; A new coumarin from Citrus grandis 'Shatianyu'; Biochemical Systematics and Ecology, 2012, 42: 124-127.

[116] Rao YK et al.; Insulin-mimetic action of rhoifolin and cosmosiin isolated from Citrus grandis (L.) Osbeck leaves: enhanced adiponectin secretion and insulin receptor phosphorylation in 3T3-L1 cells. Evidence-Based Complementary and Alternative Medicine, 2011 : 624375.

[117] Yoo KM et al.; Major phytochemical composition of 3 native Korean citrus varieties and bioactive activity on V79-4 cells induced by oxidative stress; Journal of food science, 2009, 74(6): C462 - C468.

[118] Moon JC et al.; Bioactive Materials : Article ; Induction of Apoptosis in SNU-16 Human Gastric Cancer Cells by the Chloroform Fraction of an Extract of Dangyuja (Citrus grandis) Leaves; Korea Society for Applied Biological Chemistry (Korea Society of thickening), 2009, 52(2): 168. 
[119] R Devi et al.; In vitro and in vivo Antioxidant Activity of Fresh Juice of Citrus grandis of the Northeastern Region of India; Journal of Herbs, Spices \& Medicinal Plants, 2012, 18(4): 349.

[120] Wang YC et al.; The flavonoid, carotenoid and pectin content in peels of Citrus cultivated in Taiwan. Food Chemistry, 2008, 106: $277-284$.

[121] Kim EH et al.; A prospective study of grapefruit and grapefruit juice intake and breast cancer risk. British Journal of Cancer, 2008, 98: 240-241.

[122] El Readi MZ et al.; Inhibition of P-glycoprotein activity by limonin and other secondary metabolites from Citrus species in human colon and leukaemia cell lines. European Journal of Pharmacology, 2010, 626: 139-145.

[123] Ghafoor K et al.; Optimization of supercritical fluid extraction of bioactive compounds from grape (Vitis labrusca B.) peel by using response surface methodology; Innovative Food Science and Emerging Technologies, 2010, 11(3): 485 - 490.

[124] Karacabey E et al.; Extraction of Bioactive Compounds from Milled Grape Canes (Vitis vinifera) Using a Pressurized Low-Polarity Water Extractor; Food and Bioprocess Technology, 2012, 5(1): 359 - 371.

[125] Ono E et al.; Functional differentiation of the glycosyltransferases that contribute to the chemical diversity of bioactive flavonol glycosides in grapevines (Vitis vinifera); The Plant cell, 2010, 22(8): 2856 - 2871.

[126] Yao CS et al.; A new stilbene dimer from Vitis amurensis; Journal of Asian natural products research, 2013, 15(6): 693.

[127] Guerrero RF et al. ; Induction of stilbenes in grapes by UV-C: Comparison of different subspecies of Vitis; Innovative Food Science and Emerging Technologies, 2010, 11(1): 231-238.

[128] Mewis I et al. ; Specific poly-phenolic compounds in cell culture of Vitis vinifera L. cv. Gamay Fréaux; Applied biochemistry and biotechnology, 2011, 164(2): $148-161$.

[129] Gómez-García $\mathrm{R}$ et al.; Enzyme-assisted extraction of antioxidative phenolics from grape (Vitis vinifera L.) residues. 3 Biotech, 2012, 2(4): 297-300.

[130] Lutz M et al. ; Phenolics and antioxidant capacity of table grape (Vitis vinifera L.) cultivars grown in Chile. Journal of food science, 2011, 76(7): C1088 - C1093.

[131] Ancuta N et al.; Study of Cytostatic and Cytotoxic Activity of Several Polyphenolic Extracts Obtained from Vitis vinifera; Notulae Botanicae Horti Agrobotanici Cluj-Napoca, 2012, 40(1): 216 - 221.

[132] González-Centeno MR et al.; Proanthocyanidin composition and antioxidant potential of the stem winemaking byproducts from 10 different grape varieties (Vitis vinifera L.); Journal of agricultural and food chemistry, 2012, 60(48): 11850.

[133] You Q et al.; Analysis of Phenolic Composition of Noble Muscadine (Vitis rotundifolia) by HPLC-MS and the Relationship to Its Antioxidant Capacity. Journal of Food Science, 2012, 77(10): C1115 - C1123.

[134] Anter J et al.; Targets of red grapes: oxidative damage of DNA and leukaemia cells. Natural Product Communications, 2011, 6(1): 59-64.

[135] Bijak M et al.; Anticoagulant effect of polyphenols-rich extracts from black chokeberry and grape seeds. Fitoterapia, 2011, 82(6): 811-817.

[136] Devi SA et al.; Grape seed proanthocyanidin lowers brain oxidative stress in adult and middle-aged rats. Experimental Gerontology, 2011, 46(11): 958-964.

[137] Dogan A and Celik I ; Hepatoprotective and antioxidant activities of grapeseeds against ethanol-induced oxidative stress in rats. British Journal of Nutrition, 2012, 107(1): 45-51.

[138] Plundrich $\mathrm{N}$ et al. ; Bioactive polyphenols from muscadine grape and blackcurrant stably concentrated onto protein-rich matrices for topical applications; International journal of cosmetic science, 2013, 35(4): $394-440$.

[139] Ingersoll GL et al.; Effect of concord grape juice on chemotherapy-induced nausea and vomiting: results of a pilot study. Oncology Nursing Forum, 2010, 37: 213-21.

[140] Giulio MP; Novel Role of Red Wine-Derived Polyphenols in the Prevention of Alzheimer's Disease Dementia and Brain Pathology: Experimental Approaches and Clinical Implications; Planta Medica, 2012, 79(1): 92 - 92.

[141] Abtahi $\mathrm{H}$ et al. ; Antimicrobial activities of ethanol extract of black grape; African Journal of Microbiology Research, 2011, 5(25): 4446-4448.

[142] El-Beshbishy HA et al. ; Amelioration of tamoxifen-induced liver injury in rats by grape seed extract, black seed extract and curcumin. Indian Journal of Experimental Biology, 2010, 48(3): 280-288.

[143] Fernández-Pérez $\mathrm{F}$ et al. ; Cytotoxic effect of natural trans-resveratrol obtained from elicited Vitis vinifera cell cultures on three cancer cell lines. Plant foods for human nutrition (Dordrecht, Netherlands), 2012, 67(4):422-429.

[144] Feringa $\mathrm{HH}$ et al.; The effect of grape seed extract on cardiovascular risk markers: a meta-analysis of randomized controlled trials. Journal of the American Dietetic Association, 2011, 111(8): 1173-1181.

[145] Mikstacka R et al.; Antioxidant effect of trans-resveratrol, pterostilbene, quercetin and their combinations in human erythrocytes in vitro; Plant foods for human nutrition (Dordrecht, Netherlands), 2010, 65(1): 57 - 63.

[146] Charradi K et al. ; Grape seed and skin extract prevents high-fat diet-induced brain lipotoxicity in rat; Neurochemical research, 2012, 37(9): 2004.

[147] Krikorian $\mathrm{R}$ et al.; Concord grape juice supplementation improves memory function in older adults with mild cognitive impairment. British Journal of Nutrition, 2010, 103: 730-734.

[148] Khoshbaten M et al. ; Grape seed extract to improve liver function in patients with nonalcoholic fatty liver change. Saudi Journal of Gastroenterology, 2010, 16(3): 194-197.

[149] Song X et al.; Grape seed proanthocyanidin suppression of breast cell carcinogenesis induced by chronic exposure to combined 4-(methylnitrosamino)-1-(3-pyridyl)-1-butanone and benzo[a]pyrene. Molecular Carcinogenesis, 2010, 49(5): $450-463$.

[150] Thiruchenduran $M$ et al. ; Protective effect of grape seed proanthocyanidins against cholesterol cholic acid diet-induced hypercholesterolemia in rats. Cardiovascular Pathology, 2011, 20(6): 361-368. 
[151] Wang YH et al. ; Proanthocyanidins from grape seeds modulates the nuclear factor-kappa B signal transduction pathways in rats with TNBS-induced recurrent ulcerative colitis. International Immunopharmacology, 2011, 11(10): $1620-1627$.

[152] Zhang YJ et al.; Antithrombotic effect of grape seed proanthocyanidins extract in a rat model of deep vein thrombosis. Journal of Vascular Surgery, 2011, 53(3): 743-753.

[153] Ho L et al. ; Identification of brain-targeted bioactive dietary quercetin-3-O-glucuronide as a novel intervention for Alzheimer's disease. FASEB journal, 2013, 27(2): 769 - 781.

[154] Kountouri AM et al.; Chemopreventive properties of raisins originating from Greece in colon cancer cells; Food \& Function, 2013, 4(3): 366 - 372.

[155] Delgado, T et al.; Hazelnut (Corylus avellana L.) kernels as a source of antioxidants and their potential in relation to other nuts; Industrial Crops \& Products, 2010, 32(3): 621 - 626.

[156] Bacchetta L et al.; Fatty acids and alpha-tocopherol composition in hazelnut (Corylus avellana L.): a chemometric approach to emphasize the quality of European germplasm; Euphytica, 2013, 191(1): 57 - 73.

[157] Schmitzer V et al.; Roasting affects phenolic composition and antioxidative activity of hazelnuts (Corylus avellana L.); Journal of food science, 2011, 76(1): S14 - S19.

[158] Yorulmaz Aet al. ; Phytosterols in 17 Turkish hazelnut (Corylus avellana L.) cultivars. European Journal of Lipid Science and Technology, 2009, 11(4): 402-408.

[159] Ramalhosa E et al.; Hazelnut (Corylus avellana L.) Cultivars and Antimicrobial Activity: Nuts and Seeds in Health and Disease Prevention (Chapter 73), 2011: 627-636.

[160] Park YS et al.; Comparison of the contents of bioactive compounds and the level of antioxidant activity in different kiwifruit cultivars; Journal of Food Composition and Analysis, 2011, 24(7): 963 - 970 .

[161] Cassano A et al.; Recovery of bioactive compounds in kiwifruit juice by ultrafiltration. Innovative Food Science and Emerging Technologies, 2008, 9(4): 556 - 562.

[162] Dongxiao S-W et al.; Evaluation of the extraction efficiency for polyphenol extracts from by-products of green kiwifruit juicing. International Journal of Food Science and Technology, 2009, 44(12): 2644.

[163] Chang WH and Liu JF; Effects of kiwifruit consumption on serum lipid profiles and antioxidative status in hyperlipidemic subjects. International Journal of Food Sciences and Nutrition, 2009, 60: 709-716.

[164] Mohajeri G et al.; The effect of dressing with fresh kiwifruit on burn wound healing. Surgery, 2010: 1-27.

[165] Park YS et al.; Nutritional and pharmaceutical properties of bioactive compounds in organic and conventional growing kiwifruit; Plant foods for human nutrition (Dordrecht, Netherlands), 2013, 68(1): 57 - 64.

[166] Welma S et al.; Kiwifruit: our daily prescription for health; Canadian journal of physiology and pharmacology, 2013, 91(6): $442-447$

[167] Collins AR; Kiwifruit as a Modulator of DNA Damage and DNA Repair (Chapter 16) : Nutritional Benefits of Kiwifruit.
Advances in Food and Nutrition Research, 2013, 68: 283-299.

[168] Srivastava AK; Advances in Citrus Nutrition, 2012: 1-19.

[169] Almudena B and Antonio C; Analysis of nutritional constituents in twenty citrus cultivars from the Mediterranean area at different stages of ripening, Food and Nutrition Sciences, 2012, 3(5): 639 - 650.

[170] Barros H et al.; Antioxidant capacity and mineral content of pulp and peel from commercial cultivars of citrus from Brazil. Food chemistry, 2012, 134(4): 1892.

[171] Battinelli L et al.; Effect of limonin and nomilin on HIV-1 replication on infected human mononuclear cells. Planta Medica, 2003, 69(10): 910-913.

[172] Li WQ et al.; Citrus consumption and cancer incidence: the Ohsaki cohort study. International Journal of Cancer, 2010, 127: 1913-22.

[173] Bae JM et al.; Citrus fruit intake and pancreatic cancer risk: a quantitative systematic review. Pancreas, 2009, 38: 168-174.

[174] Foschi R et al.; Citrus fruit and cancer risk in a network of case-control studies. Cancer Causes Control, 2010, 21: 237-242.

[175] Kunimasa K et al.; Nobiletin, a citrus polymethoxyflavonoid, suppresses multiple angiogenesis-related endothelial cell functions and angiogenesis in vivo. Cancer Science., 2010, 101: 2462-2469.

[176] Patil JR et al.; Bioactive compounds from Mexican lime (Citrus aurantifolia) juice induce apoptosis in human pancreatic cells. Journal of Agricultural and Food Chemistry, 2009, 57: 10933-10942.

[177] Adepoju G and Adeyemi T; Evaluation of the effect of lime fruit juice on the anticoagulant effect of warfarin. Journal of Young Pharmacists, 2010, 2: 269-72.

[178] Patil JR et al.; Characterization of Citrus aurantifolia bioactive compounds and their inhibition of human pancreatic cancer cells through apoptosis. Microchemical Journal, 2010, 94(2): 108-117.

[179] Ercisli S and al. ; Some physicochemical characteristics, bioactive content and antioxidant capacity of loquat (Eriobotrya japonica (Thunb.) Lindl.) fruits from Turkey. Scientia Horticulturae, 2012, 148: 185 - 189.

[180] Xu H and Chen J; Commercial quality, major bioactive compound content and antioxidant capacity of 12 cultivars of loquat (Eriobotrya japonica Lindl.) fruits. Journal of the Science of Food and Agriculture, 2011, 91(6) : 1057 - 1063.

[181] Kim MS et al.; Oral administration of loquat suppresses DMBA-induced breast cancer in rats. Food Science and Biotechnology, 2011, 20(2) : 491 - 497.

[182] Shih CC et al.; Eriobotrya japonica improves hyperlipidemia and reverses insulin resistance in high-fat-fed mice. Phytotherapy research, 2010, 24(12): $1769-1780$.

[183] Rollinger JM et al.; 11 $\beta$-Hydroxysteroid dehydrogenase 1 inhibiting constituents from Eriobotrya japonica revealed by bioactivity-guided isolation and computational approaches. Bioorganic \& Medicinal Chemistry, 2010, 18(4) : 1507 - 1515.

[184] Chang CT et al.; Anti-inflammatory activities of tormentic acid from suspension cells of Eriobotrya Japonica ex vivo and in vivo. Food Chemistry, 2011, 127(3): $1131-1137$. 
[185] Ribeiro SMR and Schieber A; Bioactive Compounds in Mango (Mangifera indica L.): Bioactive Foods in Promoting Health (Chapter 34), $2010:$ 507-523.

[186] Amitha KH et al.; Between fruit variability of the bioactive compounds, $\beta$-carotene and mangiferin, in mango (Mangifera indica); Nutrition \& Dietetics, 2013, 70(2): 158 - 163.

[187] Ajila CM et al.; Characterization of bioactive compounds from raw and ripe Mangifera indica L. peel extracts; Food and Chemical Toxicology, 2010, 48(12): 3406 - 3411.

[188] Sokindra K et al.; Effects of Mangifera indica fruit extract on cognitive deficits in mice; Journal of environmental biology / Academy of Environmental Biology, India, 2009, 30(4): 563 566.

[189] Noratto GD et al.; Anticarcinogenic effects of polyphenolics from mango (Mangifera indica) varieties. Journal of agricultural and food chemistry, 2010, 58(7): 4104-4112.

[190] Pourahmad J et al.; A search for hepatoprotective activity of fruit extract of Mangifera indica $L$. against oxidative stress cytotoxicity. Plant Foods Hum Nutr, 2010, 65(1): 83-89.

[191] Núñez FY et al.; A Strong Protective Action of Guttiferone-A, a Naturally Occurring Prenylated Benzophenone, Against Iron-Induced Neuronal Cell Damage. Journal of Pharmacological Sciences, 2011, 116(1):36-46.

[192] Saranyu K and Rakrudee S; Antioxidant and antibacterial activities of selected varieties of thai mango seed extract; Pakistan journal of pharmaceutical sciences, 2011, 24(1): 37.

[193] Maietti A et al.; Analytical traceability of melon (Cucumis melo var reticulatus): proximate composition, bioactive compounds, and antioxidant capacity in relation to cultivar, plant physiology state, and seasonal variability; Journal of food science, 2012, 77(6): C646- C652.

[194] Nakamura Y et al.; Antimutagenic; differentiation-inducing; and antioxidative effects of fragrant ingredients in Katsura-uri (Japanese pickling melon; Cucumis melo var. conomon). Mutation Research, 2010, 703(2): 163-168.

[195] Pereira JA et al.; Bioactive properties and chemical composition of six walnut (Juglans regia L.) cultivars. Food and chemical toxicology, 2008, 46(6): 2103 - 2111.

[196] Özrenk, K et al.; Fatty acids, tocopherols, selenium and total carotene of pistachios (P. vera L.) from Diyarbakır (Southestern Turkey) and walnuts (J. regia L.) from Erzincan (Eastern Turkey); Food Science and Technology International, 2012, 18(1): 55-62.

[197] Lei Z et al.; Simultaneous determination of four flavonoid aglycone analogs in the inflorescence of juglans regia L. By high-performance liquid chromatography-diode array detection. Journal of Liquid Chromatography \& Related Technologies, 2013, 36(14): 1986.

[198] Sharma N et al.; Antioxidant potential of Juglans regia bark: quantification of seven phenolic compounds by RP-HPLC; Food Science and Technology International, 2012, 18(1): 55 62.

[199] Hosseinzadeh H et al.; Antinociceptive, Anti-Inflammatory and Acute Toxicity Effects of Juglans Regia L. Leaves in Mice; Iranian Red Crescent Medical Journal, 2011, 13(1): 27 - 33.

[200] Vanden HJP et al.; Mechanistic examination of walnuts in prevention of breast cancer; Nutrition and cancer, 2012, 64(7): 1078.

[201] Fernandez-Agullo A et al.; Influence of solvent on the antioxidant and antimicrobial properties of walnut (Juglans regia L.) green husk extracts; Industrial Crops and Products, 2013, 42: 126 - 132.

[202] Ali AA et al.; Validation of the Antiproliferative Effects of Organic Extracts from the Green Husk of Juglans regia L. on PC-3 Human Prostate Cancer Cells by Assessment of Apoptosis-Related Genes; Evidence-based complementary and alternative medicine : eCAM, 2012, 2012: 103026.

[203] Muthaiyah, Balu et al.; Protective Effects of Walnut Extract Against Amyloid Beta Peptide-Induced Cell Death and Oxidative Stress in PC12 Cells; Neurochemical Research, 2011, 36(11): 2096 - 2103.

[204] Carvalho $M$ et al.; Human cancer cell antiproliferative and antioxidant activities of Juglans regia L; Food and Chemical Toxicology, 2010, 48(1):. 441 - 447.

[205] Dergisi KT; Olive Oil and Health: Bioactive Constituents, Antioxidant Properties and Clinical Implications; Hepatology (4th ed), 2013, 5(1): 60 - 68 .

[206] Eduardo $M$ et al.; New genotypes of table olives: profile of bioactive compounds; International Journal of Food Science \& Technology, 2012, 47(11): 2334 - 2341.

[207] Michel T et al.; Oleacin and oleocanthal: Two olive oil bioactives in multiple chemical forms; Planta Medica, 2012, 78(11): PJ43.

[208] Barbara G et al.; A simple method for the determination of bioactive antioxidants in virgin olive oils. Journal of the Science of Food and Agriculture, 2013, 93(7): 1727 - 1732.

[209] Mavrakis T et al.; Application of bioactive plant substances from olive tissues and grapes in non-chemical disease control. Phytopathologia Mediterranea, 2009, 48(2): 345 - 345.

[210] Rahele G et al.; Valuable Nutrients and Functional Bioactives in Different Parts of Olive (Olea europaea L.) - A Review. International journal of molecular sciences, 2012, 13(3): 3291 -3340 .

[211] Belnaser $\mathrm{AB}$ et al.; Olive secoiridoids and semisynthetic bioisostere analogues for the control of metastatic breast cancer. Bioorganic \& medicinal chemistry, 2013, 21(7): 2117-2127.

[212] Jayaprakasha GK et al.; Bioactive compounds from sour orange inhibit colon cancer cell proliferation and induce cell cycle arrest; Journal of agricultural and food chemistry, 2010, 58(1): 180 - 186.

[213] Zong-Tsi C et al.; Protective effects of sweet orange (Citrus sinensis) peel and their bioactive compounds on oxidative stress; Food chemistry, 2012, 135(4): 2119.

[214] Toledo-Guillén AR et al.; Extraction of Bioactive Flavonoid Compounds from Orange (Citrus sinensis) Peel Using Supercritical CO2; Journal of Biotechnology, 2010, 150: 313-314.

[215] Karoui J et al.; Characterization of bioactive compounds in Tunisian bitter orange (Citrus aurantium L.) peel and juice and determination of their antioxidant activities. BioMed research international, 2013, 2013: 345415. 
[216] Coelho RCLA et al.; Anti-inflammatory Properties of Orange Juice: Possible Favorable Molecular and Metabolic Effects; Plant Foods for Human Nutrition, 2013, 68(1): 1-10.

[217] Stinco CM et al.; Bioaccessibility, antioxidant activity and colour of carotenoids in ultrafrozen orange juices: Influence of thawing conditions; LWT - Food Science and Technology, 2013, 53(2): 458

[218] Tainara De Moraes C et al.; Dietary fiber from orange byproducts as a potential fat replacer; LWT - Food Science and Technology, 2013, 53(1): 9.

[219] Crifò T et al.; Short cold storage enhances the anthocyanin contents and level of transcripts related to their biosynthesis in blood oranges; Journal of agricultural and food chemistry, 2012, 60(1): 476 .

[220] Cesar TB et al.; Orange juice decreases low-density lipoprotein cholesterol in hypercholesterolemic subjects and improves lipid transfer to high-density lipoprotein in normal and hypercholesterolemic subjects. Nutrition Research, 2010, 30: 689-94.

[221] Morand $\mathrm{C}$ et al.; Hesperidin contributes to the vascular protective effects of orange juice: a randomized crossover study in healthy volunteers. American Journal of Clinical Nutrition, 2011, 93: 73-80.

[222] Yujing S et al.; Phytochemical profile and antioxidant activity of physiological drop of citrus fruits; Journal of food science, 2013, 78(1): C37 - C42.

[223] Jinhee $\mathrm{K}$ et al.; Limonoids and their anti-proliferative and anti-aromatase properties in human breast cancer cells; Food \& function, 2013, 4(2): 258 - 265.

[224] Abidi W et al.; Evaluation of Antioxidant Compounds and Total Sugar Content in a Nectarine [Prunus persica (L.) Batsch] Progeny; International journal of molecular sciences, 2011, 12(10): 6919 - 6935.

[225] Manzoor $\mathrm{M}$ et al.; Variation in minerals, phenolics and antioxidant activity of peel and pulp of different varieties of peach (Prunus persica L.) fruit from Pakistan; Molecules (Basel, Switzerland), 2012, 17(6): 6491 - 650.

[226] Legua P et al.; Quality, bioactive compounds, and antioxidant activity of new flat-type peach and nectarine cultivars: a comparative study Journal of food science, 2011, 76(5): C729-C735.

[227] Emilio AP et al. ; Phytochemical Composition and Health Aspects of Peach Products: Dried Fruits: Phytochemicals and Health Effects (Chapter17). 2013: 310-324.

[228] Muhammad S et al. ; Peaches and Nectarines: Handbook of Fruits and Fruit Processing (2nd Ed); 2012 : 535-549.

[229] Han S et al.; Anti-photoaging effects of 2-methoxy-5-(2-methyl propyl) pyrazine isolated from peach (Prunus persica (L.) Batsch); Food Science and Biotechnology, 2010, 19(6): 1667 . 1671.

[230] Alasalvar C and Shahidi F; Drying Nectarines: Functional Compounds and Antioxidant Potential Dried Fruits: Phytochemicals and Health Effects (Chapter16), 2013: 293-309;

[231] Carpentier S et al. ; Associations between lutein, zeaxanthin, and age-related macular degeneration: an overview. Critical Reviews in Food Science and Nutrition, 2009, 49:313-26.
[232] Olga B et al.; Nectarine promotes longevity in Drosophila melanogaster; Free Radical Biology and Medicine, 2011, 50(11): 1669-1678.

[233] Lee CK et al.; The extract of Prunus persica flesh (PPFE) attenuates chemotherapy-induced hepatotoxicity in mice. Phytotherapy Research, 2008, 22(2): 223-227.

[234] Lee CK et al.; Extract of Prunus persica flesh (PPFE) improves chemotherapeutic efficacy and protects against nephrotoxicity in cisplatin-treated mice. Phytotherapy Research, 2009, 23(7): 999-1005.

[235] Atwill RL et al. ; Bioproduction and purification of prenylated resveratrol analogs from hairy root cultures of peanut. Planta Medica, 2012, 78(11): PB12.

[236] Brittany LW et al.; Development of a pilot-scale process to sequester aflatoxin and release bioactive peptides from highly contaminated peanut meal. LWT - Food Science and Technology, 2013, 51(2): 492-499.

[237] Yeh CC et al. ; Peanut consumption and reduced risk of colorectal cancer in women: a prospective study in Taiwan. World Journal of Gastroenterology, 2006, 12(2): 222-227.

[238] Hasan MM et al. ; Production of a major stilbene phytoalexin, resveratrol in peanut (Arachis hypogaea) and peanut products: a mini review. Reviews in Environmental Science and Bio/Technology, 2013, 12(3): 209 - 221.

[239] Ma JN et al.; Chemical Components and Antioxidant Activity of the Peels of Commercial Apple-Shaped Pear (Fruit of Pyrus pyrifolia cv. pingguoli); Journal of Food Science, 2012, 77(10): C1097 - C1102.

[240] Salta J et al.; Phenolic composition and antioxidant activity of Rocha pear and other pear cultivars - A comparative study. J Funct Food, 2010, 2(2): 153-157.

[241] Alvarez-Parrilla E et al.; Daily consumption of apple, pear and orange juice differently affects plasma lipids and antioxidant capacity of smoking and non-smoking adults. International Journal of Food Sciences and Nutrition, 2010, 61: 369-380.

[242] Larsson, S et al.; Total and specific fruit and vegetable consumption and risk of stroke: a prospective study. Atherosclerosis, 2013, 227(1): 147.

[243] Sivanesan D et al.; Bromelain-Induced Apoptosis in GI-101A Breast Cancer Cells, Journal of medicinal food, 2012, 15(4): $344-349$

[244] Rajendra P et al. ; Properties and therapeutic application of bromelain: a review, Biotechnology research international, 2012, 2012: 976203 .

[245] Chobotova $\mathrm{K}$ et al. ; Bromelain's activity and potential as an anti-cancer agent: Current evidence and perspectives. Cancer Lett, 2010, 290: 148-156.

[246] Juhasz B et al. ; Bromelain induces cardioprotection against ischemia-reperfusion injury through $\mathrm{Akt} / \mathrm{FOXO}$ pathway in rat myocardium. American journal of physiology - Heart and circulatory physiology, 2008, 294: H1365-H1370.

[247] Gentile C et al.; Polymeric proanthocyanidins from Sicilian pistachio (Pistacia vera L.) nut extract inhibit lipopolysaccharide-induced inflammatory response in RAW 264.7 cells; European journal of nutrition, 2012, 51(3): 353-363. 
[248] Marinou KA et al.; Differential effect of Pistacia vera extracts on experimental atherosclerosis in the rabbit animal model: an experimental study. Lipids in health and disease, 2010, 9(1): 73-79.

[249] Tomaino A et al.; Antioxidant activity and phenolic profile of pistachio (Pistacia vera L., variety Bronte) seeds and skins. Biochimie, 2010, 92(9): 1115-1122.

[250] Marcello S et al.; Compounds with Antioxidant Properties in Pistachio (Pistacia vera L.) Seeds; Nuts and Seeds in Health and Disease Prevention, 2011: 909-918.

[251] West SG et al.; Pistachios reduce blood pressure and vascular responses to acute stress in healthy adults. FASEB Journal, 2010, 21: 682-686.

[252] Kay CD et al.; Pistachios increase serum antioxidants and lower serum oxidized-LDL in hypercholesterolemic adults. Journal of Nutrition, 2010, 140(6): 1093-1098.

[253] María PF et al; Pistachio (Pistacia vera var Kerman) from Argentinean cultivars. A natural product with potential to improve human health. Journal of Functional Foods, 2013, 5(3): 1347-1356.

[254] Maria M et al.; In vitro antioxidant and in vivo photoprotective effect of pistachio (Pistacia vera L., variety Bronte) seed and skin extracts. Fitoterapia, 2013, 85: 41-48.

[255] Askari $\mathrm{G}$ et al.; The relationship between nut consumption and lipid profile among the Iranian adult population; Isfahan Healthy Heart Program; European Journal of Clinical Nutrition, 2013, 67(4): 385 - 389.

[256] Legua $\mathrm{P}$ et al.; Total phenols and antioxidant capacity in 10 Moroccan pomegranate varieties; Journal of food science, 2012, 77(1): C115 - C120.

[257] Mehdi Z et al.; Evaluation of physicochemical characteristics of pomegranate (Punica granatum L.) fruit during ripening; Fruits, 2011, 66(2): 121 - 129.

[258] Yuan T et al.; Punicatannins $A$ and B: $\alpha$-glucosidase inhibitory ellagitannins from pomegranate (Punica granatum) flowers; Planta Medica, 2012, 78(11): PI154.

[259] Valerio C et al.; Fruit quality of Italian pomegranate (Punica granatum L.) autochthonous varieties. European Food Research and Technology, 2011, 232(3): 397 - 403.

[260] Pedro M et al.; Phytochemical characterisation for industrial use of pomegranate (Punica granatum L.) cultivars grown in Spain; Journal of the Science of Food and Agriculture, 2011, 91(10): 1893 - 1906.

[261] Cavalcanti RN et al.; Supercritical Carbon Dioxide Extraction of Polyphenols from Pomegranate (Punica granatum L.) Leaves: Chemical Composition, Economic Evaluation and Chemometric Approach. Journal of Food Research, 2012, 1(3): 282-294.

[262] Elena S et al.; Influence of the genotype on the anthocyanin composition, antioxidant capacity and color of Chilean pomegranate (Punica granatum L.) juices. Chilean Journal of Agricultural Research, 2010, 70(1): 50-57.

[263] Paz R et al.; Encapsulation of polyphenols and anthocyanins from pomegranate. International Journal of Food Science and Technology, 2010, 45(7): 1386.
[264] Walid E et al.; Antioxidant Capacities of Phenolic Compounds and Tocopherols from Tunisian Pomegranate (Punica granatum) Fruits. Journal of Food Science, 2011, 76(5): C707 C713.

[265] Jasuja ND et al.; Pharmacological Characterization and Beneficial Uses of Punica granatum; Asian Journal of Plant Sciences, 2012, 11(6): 251 - 267.

[266] Ira G et al.; Partial identification of antifungal compounds from Punica granatum peel extracts. Journal of agricultural and food chemistry, 2012, 60(19): 4841.

[267] Hashemi $\mathrm{M}$ et al.; Acute and long-term effects of grape and pomegranate juice consumption on vascular reactivity in paediatric metabolic syndrome. Cardiology in the Young, 2010, 20: 73-77.

[268] Sturgeon SR and Ronnenberg AG; Pomegranate and breast cancer: possible mechanisms of prevention. Nutrition Reviews, 2010, 68: 122-128.

[269] Kasimsetty SG et al.; Colon cancer chemopreventive activities of pomegranate ellagitannins and urolithins. Journal of agricultural and food chemistry, 2010, 58: 2180-2187.

[270] Zahin $M$ et al.; Broad spectrum antimutagenic activity of antioxidant active fraction of Punica granatum $L$. peel extracts. Mut.Res.-Genetic Toxicology and Environmental Mutagenesis, 2010, 703(2): 99-107.

[271] Velayutham DM et al.; In vitro and in vivo evaluation of antioxidant and antigenotoxic potential of Punica granatum leaf extract. Pharmaceutical biology, 2012, 50(12): 1523.

[272] Haytham D et al.; Bioactive actions of pomegranate fruit extracts on leukemia cell lines in vitro hold promise for new therapeutic agents for leukemia. Nutrition and cancer, 2012, 64(1): 100 .

[273] Glauce SBV et al.; Biological Effects of Pomegranate (Punica granatum L.), especially its Antibacterial Actions, Against Microorganisms Present in the Dental Plaque and Other Infectious Processes; Bioactive Foods in Promoting Health (Chapter31); 2010 : 457-478.

[274] Jinhee K et al. ; Potential Chemopreventive Effect of Bioactives from Cactus (Opuntia ficus-indica) Stem. Horticultural Science and Technology, 2013, 31(S1) : 183 183.

[275] Nadia C et al. ; Oil composition and characterisation of phenolic compounds of Opuntia ficus-indica seeds. Food chemistry, 2013, 139(1-4): 796.

[276] Sara B et al. ; By-products of Opuntia ficus-indica as a source of antioxidant dietary fiber ; Plant foods for human nutrition (Dordrecht, Netherlands), 2010, 65(3): 210 - 216.

[277] Gandía-Herrero F et al. ; Stabilization of the bioactive pigment of opuntia fruits through maltodextrin encapsulation. Journal of agricultural and food chemistry, 2010, 58(19): 10646.

[278] Coria C et al. ; Health-promoting substances and antioxidant properties of Opuntia sp. fruits. Changes in bioactive-compound contents during ripening process. Food Chemistry, 2011, 126(2): 514 - 519.

[279] Fernández-López JA et al. ; Determination of antioxidant constituents in cactus pear fruits. Plant Foods Hum Nutr, 2010, 65(3): 253-259. 
[280] Tesoriere L et al.; Phytochemical indicaxanthin suppresses 7-ketocholesterol-induced THP-1 cell apoptosis by preventing cytosolic $\mathrm{Ca}^{2+}$ increase and oxidative stress ; The British journal of nutrition, 2013, 110(2): 230 - 240 .

[281] Moussa-Ayoub TE et al. ; Flavonols, betacyanins content and antioxidant activity of cactus Opuntia macrorhiza fruits. Food Research International, 2011, 44(7): 2169 - 2174.

[282] Moussa-Ayoub TE et al. ; Identification and quantification of flavonol aglycons in cactus pear (Opuntia ficus indica) fruit using a commercial pectinase and cellulase preparation Food Chemistry, 2011, 124(3): 1177 - 1184.

[283] Yahia Em and Mondragon-Jacobo C ; Nutritional components and anti-oxidant capacity of ten cultivars and lines of cactus pear fruit (Opuntia spp.). Food Research International, 2011, 44(7): $2311-2318$.

[284] Godard MP et al. ; Acute blood glucose lowering effects and long-term safety of Opuntia supplementation in pre-diabetic males and females. Journal of Ethnopharmacology, 2010, 130(3): 631-634.

[285] Kim JM et al. ; The n-butanolic extract of Opuntia ficus-indica var. saboten enhances long-term memory in the passive avoidance task in mice. Progress in Neuro-Psychopharmacology and Biological Psychiatry, 2010, 34(6): 1011-1017.

[286] Usenik, V et al.; Phytochemicals in fruits of two Prunus domestica L. plum cultivars during ripening; Journal of the science of food and agriculture, 2013, 93(3): 681 - 692.

[287] Rendina, E et al.; Dietary supplementation with dried plum prevents ovariectomy-induced bone loss while modulating the immune response in C57BL/6J mice; The Journal of nutritional biochemistry, 2012, 23(1): $60-68$.

[288] Nemanja M et al.; Phenolic content and antioxidant capacity of fruits of plum cv. 'Stanley' (Prunus domestica L.) as influenced by maturity stage and on-tree ripening; Australian Journal of Crop Science, 2012, 6(4): 681.

[289] Milala J et al.; Plum pomaces as a potential source of dietary fibre: composition and antioxidant properties; Journal of Food Science and Technology, 2013, 50(5): 1012 - 1017.

[290] Ahmed T et al.; Use of prunes as a control of hypertension. Journal of Ayub Medical College Abbottabad, 2010, 22(1): 28-31.

[291] Ahmed T et al.; Report: prunes and liver function: a clinical trial. Pakistan Journal of Pharmaceutical Sciences, 2010, 23(4): 463-466.

[292] Mahmood A et al.; Structural determination of prunusins A and B, new C-alkylated flavonoids from Prunus domestica, by 1D and 2D NMR spectroscopy. Magnetic Resonance in Chemistry, 2010, 48(2): 151-154

[293] Shannon MS et al.; Juice, pulp and seeds fractionated from dry climate primocane raspberry cultivars (Rubus idaeus) have significantly different antioxidant capacity, anthocyanin content and color. Plant foods for human nutrition (Dordrecht, Netherlands), 2012, 67(4): 358.

[294] Yousefi $G$ et al.; A comparative study on different concentration methods of extracts obtained from two raspberries (Rubus idaeus L.) cultivars: evaluation of anthocyanins and phenolics contents and antioxidant activity.
International Journal of Food Science \& Technology, 2013, 48(6): $1179-1186$.

[295] Bobinaitė R et al.; Variation of total phenolics, anthocyanins, ellagic acid and radical scavenging capacity in various raspberry (Rubus spp.) cultivars. Food Chemistry, 2012, 132(3): $1495-1501$.

[296] Bushakra JM et al.; QTL involved in the modification of cyanidin compounds in black and red raspberry fruit. Theoretical and Applied Genetics, 2013, 126(3): 847 - 865.

[297] Borges $G$ et al. ; Identification of Flavonoid and Phenolic Antioxidants in Black Currants, Blueberries, Raspberries, Red Currants, and Cranberries. Journal of agricultural and food chemistry, 2010, 58: 3901-3909.

[298] Elisabete C et al.; Carotenoids and tocopherols in yellow and red raspberries. Food chemistry, 2013, 139(1-4): 744.

[299] Ksenija D et al.; The Bioactive Potential of Red Raspberry (Rubus idaeus L.) Leaves in Exhibiting Cytotoxic and Cytoprotective Activity on Human Laryngeal Carcinoma and Colon Adenocarcinoma. Journal of medicinal food, 2012, 15(3): 258 - 268.

[300] Jean-Gilles et al.; Anti-Inflammatory Effects of Polyphenolic-Enriched Red Raspberry Extract in an Antigen Induced Arthritis Rat Model. Journal of Agricultural and Food Chemistry, 2013: 1-14

[301] Liaqat A et al.; Effects of nutrition strategy on the levels of nutrients and bioactive compounds in blackberries; European Food Research and Technology, 2012, 234(1): 33 - 44.

[302] Sylwia F et al.; Evaluation of inhibition of cancer cell proliferation in vitro with different berries and correlation with their antioxidant levels by advanced analytical methods; Journal of pharmaceutical and biomedical analysis, 2012, 62: 68-78.

[303] Stoner GD et al.; Multiple berry types prevent $\mathrm{N}$-nitrosomethylbenzylamine-induced esophageal cancer in rats. Pharmaceutical Research, 2010, 27(6): 1138-1145.

[304] McDougall GJ et al. ; Berry extracts exert different antiproliferative effects against cervical and colon cancer cells grown in vitro. Journal of agricultural and food chemistry, 2008, 56(9): 3016-3023.

[305] Bowen-Forbes CS et al.; Anthocyanin content, antioxidant, anti-inflammatory and anticancer properties of blackberry and raspberry fruits; Journal of Food Composition and Analysis, 2010, 23(6): 554 - 560.

[306] Kim SK et al.; Comparison of Bioactive Compounds Contents in 21 Major Strawberry Cultivars; Horticultural Science and Technology; 2011, 29(S1): 74-78.

[307] Fredericks, Charissa $\mathrm{H}$ et al.; High-anthocyanin strawberries through cultivar selection; Journal of the science of food and agriculture, 2013, 93(4): $846-852$.

[308] Kim SK et al.; Comparison of Bioactive Compounds Contents in Different Fruit Tissues of June-bearing Strawberry Cultivars. Horticultural Science and Technology; 2010, 28(6): 948 - 953.

[309] Sara T et al.; Impact of strawberries on human health: insight into marginally discussed bioactive compounds for the Mediterranean diet. Public Health Nutrition, 2009, 12(9A): $1656-1662$. 
[310] Giampieri F et al.; Phytochemical profiling of strawberry fruits, and bioactive compounds from the same selected cultivar in human plasma during a medium-term consumption study. BMC Proceedings, 2012, 6(Supp13): P5.

[311] Henning SM et al.; Strawberry Consumption Is Associated with Increased Antioxidant Capacity in Serum. Journal of Medicinal Food, 2010, 13: 116-122.

[312] Burton-Freeman B et al.; Strawberry Modulates LDL Oxidation and Postprandial Lipemia in Response to High-Fat Meal in Overweight Hyperlipidemic Men and Women. The Journal of the American College of Nutrition., 2010, 29(1): 46-54.

[313] Harini SA et al.; Prevention of oxidative DNA damage by bioactive berry components. Nutrition and cancer, 2008, 60(Supp11): 36 - 42 .

[314] Sara T et al.; Strawberry consumption improves plasma antioxidant status and erythrocyte resistance to oxidative haemolysis in humans; Food Chemistry, 2011, 128(1): 180 186.

[315] Riahi A and Hdider C; Bioactive compounds and antioxidant activity of organically grown tomato (Solanum lycopersicum $L$.) cultivars as affected by fertilization. Scientia Horticulturae, 2013, 151: 90 - 96.

[316] Riadh I et al.; Phytochemical composition and antioxidant activity of high-lycopene tomato (Solanum lycopersicum L.) cultivars grown in Southern Italy. Scientia Horticulturae, 2011, 127(3): 255-261.

[317] Charanjit $\mathrm{K}$ et al.; Functional quality and antioxidant composition of selected tomato (Solanum lycopersicon L) cultivars grown in Northern India; LWT - Food Science and Technology, 2013, 50(1): 139-145.

[318] Ana MA et al.; Evaluation and selection of tomato accessions (Solanum section Lycopersicon) for content of lycopene, $\beta$-carotene and ascorbic acid; Journal of Food Composition and Analysis, 2010, 23(6): 613-618.

[319] Fuentes E et al. ; Bioassay-Guided Isolation and HPLC Determination of Bioactive Compound That Relate to the Antiplatelet Activity (Adhesion, Secretion, and Aggregation) from Solanum lycopersicum; eCAM, 2012, 2012: 147031.

[320] Polívková Z et al. ; Antimutagenic effects of lycopene and tomato purée. Journal of Medicinal Food, 2010, 13(6): $1443-1450$

[321] Yoshida K et al.; Evaluation of the effect of dietary lycopene, the main carotenoid in tomato (Lycopersicon esculentum), on the in vivo renal reducing ability by a radiofrequency electron paramagnetic resonance method. Journal of agricultural and food chemistry, 2011, 59(7) : 2966-2971.

[322] Nwokocha CR et al. ; Comparative analysis on the effect of Lycopersicon esculentum (tomato) in reducing cadmium, mercury and lead accumulation in liver. Food and Chemical Toxicology, 2012, 50(6):2070-2073.

[323] Violeta N et al.; Antioxidant Compounds, Mineral Content and Antioxidant Activity of Several Tomato Cultivars Grown in Southwestern Romania. Notulae Botanicae Horti Agrobotanici Cluj-Napoca, 2013, 41(1): 136 - 142.

[324] Choi SH et al.; Free amino acid and phenolic contents and antioxidative and cancer cell-inhibiting activities of extracts of
11 greenhouse-grown tomato varieties and 13 tomato-based foods. Journal of agricultural and food chemistry, 2011, 59(24): 12801-12814.

[325] Dhirhe $\mathrm{T}$ et al.; Radio-protective effect of Lycopersicon esculentum extract against radiation induced chromosomal aberration in Swiss albino mice. International Journal of Pharmaceutical Sciences Review and Research, 2011, 7(1): 97-99.

[326] Fujiwara Y et al. ; Tomatidine, a tomato sapogenol, ameliorates hyperlipidemia and atherosclerosis in apoE-deficient mice by inhibiting acyl-CoA:cholesterol acyl-transferase (ACAT). Journal of agricultural and food chemistry, 2012, 60(10): 2472-2479.

[327] Yoshida K et al. ; Evaluation of the effect of dietary lycopene, the main carotenoid in tomato (Lycopersicon esculentum), on the in vivo renal reducing ability by a radiofrequency electron paramagnetic resonance method. Journal of agricultural and food chemistry, 2011, 59(7): 2966-2971.

[328] Shieh JM et al. ; $\alpha$-Tomatine suppresses invasion and migration of human non-small cell lung cancer NCI-H460 cells through inactivating $\mathrm{FAK} / \mathrm{PI} 3 \mathrm{~K} / \mathrm{Akt}$ signaling pathway and reducing binding activity of NF-kB. Cell Biochemistry and Biophysics, 2011, 60(3):297-310.

[329] Tan HL et al. ; Tomato-based food products for prostate cancer prevention: what have we learned? Cancer and Metastasis Reviews, 2010, 29(3) : 553 - 568.

[330] Salawu EO; Lycopersicon esculentum (tomato) prevents adverse effects of lead on blood constituents. Malaysian Journal of Medical Sciences, 2010, 17(3): 13-18.

[331] Nohara T et al. ; The tomato saponin, esculeoside A. Journal of Natural Products, 2010, 73(10): 1734-1741.

[332] Nohara T; Efficacy of tomato-saponin, esculeoside A. Journal of Traditional and Complementary Medicine, 2010, 27: 217-224.

[333] Manabe $\mathrm{H}$ et al.; Content variations of the tomato saponin esculeoside A in various processed tomatoes. Journal of Natural Medicines, 2011, 65(1): 176-179.

[334] Lee ST et al.; Alpha-tomatine induces apoptosis and inhibits nuclear factor-kappa B activation on human prostatic adenocarcinoma PC-3 cells. PLoS One, 2011, 6(4): e18915.

[335] Uppala PT et al.; Selective Inhibition of Cell Proliferation by Lycopene in MCF-7 Breast Cancer Cells In vitro: A Proteomic Analysis; Phytotherapy Research, 2013, 27(4): 595 - 601.

[336] Jacques PF et al. ; Relationship of lycopene intake and consumption of tomato products to incident CVD; The British journal of nutrition, 2013, 110(3): 545.

[337] Tommonaro G et al. ; Bioactivity of Tomato Hybrid Powder: Antioxidant Compounds and Their Biological Activities; Journal of medicinal food, 2013, 16(4): 351 - 356.

[338] Zuniga KE et al. ; The Interactions of Dietary Tomato Powder and Soy Germ on Prostate Carcinogenesis in the TRAMP Model; Cancer prevention research (Philadelphia, Pa.), 2013, 6(6): 548 .

[339] Tlili I et al.; Bioactive compounds and antioxidant activities during fruit ripening of watermelon cultivars; Journal of Food Composition and Analysis, 2011, 24(7): 923- 928. 
[340] Tarazona-Díaz MP et al.; Bioactive compounds from flesh and by-product of fresh-cut watermelon cultivars; Journal of the science of food and agriculture, 2011, 91(5): 805 - 812.

[341] Tlili I et al.; Bioactive compounds and antioxidant activities of different watermelon (Citrullus lanatus (Thunb.) Mansfeld) cultivars as affected by fruit sampling area; Journal of Food Composition and Analysis, 2011, 24(3) : 307 - 314.

[342] Oms-Oliu G et al.; Effects of high-intensity pulsed electric field processing conditions on lycopene, vitamin $\mathrm{C}$ and antioxidant capacity of watermelon juice. Food Chemistry, 2009, 115(4): 1312 - 1319.

[343] Ambreen N et al.; Antioxidant Indices of Watermelon Juice and Lycopene Extract; Pakistan Journal of Nutrition, 2013, 12(3): 255.

[344] Abdelwahab SI et al.; Anti-inflammatory activities of cucurbitacin E isolated from Citrullus lanatus var. citroides: Role of reactive nitrogen species and cyclooxygenase enzyme inhibition; Fitoterapia, 2011, 82(8): 1190.

[345] Gill NS et al.; Evaluation of antioxidant, anti-inflammatory and analgesic potential of citrullus lanatus seed extract in rodent model; The Internet Journal of Nutrition and Wellness, 2010, 9(2) : 12-34.

[346] Poduri A et al.; Citrullus lanatus 'sentinel' (watermelon) extract reduces atherosclerosis in LDL receptor-deficient mice; The Journal of nutritional biochemistry, 2013, 24(5): 882.

[347] Abu-Reidah IM et al.; Profiling of phenolic and other polar constituents from hydro-methanolic extract of watermelon (Citrullus lanatus) by means of accurate-mass spectrometry (HPLC-ESI-QTOF-MS); Food Research International, 2013, 51(1) : 354-362.

[348] Teugwa CM et al.; Anti-hyperglycaemic globulins from selected Cucurbitaceae seeds used as antidiabetic medicinal plants in Africa; BMC complementary and alternative medicine, 2013, 13: 63.

[349] Figueroa A et al.; Effects of Watermelon Supplementation on Aortic Blood Pressure and Wave Reflection in Individuals With Prehypertension: A Pilot Study. American Journal of Hypertension, 2011, 24(1): 40-44.

[350] Munglue P et al.; The Effects of Watermelon (Citrullus lanatus) Extracts and 1-Citrulline on Rat Uterine Contractility; Reproductive Sciences, 2013, 20(4): 437 - 448.

[351] Gomes FS et al.; Watermelon juice pretreatment with microfiltration process for obtaining lycopene; International Journal of Food Science \& Technology, 2013, 48(3): 601 - 608.

[352] Chen JP et al. ; Effects of different drying treatments on the stability of carotenoids in Taiwanese mango (Mangifera indica L.). Food Chemistry, 2007, 100: 1005-1010.

[353] Le Marchand L ; Cancer preventive effects of flavonoids: A review. Biomedicine and Pharmacotherapy, 2002, 56: 296-301.

[354] Nijveldt RJ et al. ; Flavonoids: a review of probable mechanisms of action and potential applications. American Journal of Clinical Nutrition, 2001, 74: 418-425.

[355] Duttaroy AK; Cardioprotective properties of kiwifruit: Nutritional Benefits of Kiwifruit (Chapter 15). Advances in Food and Nutrition Research, 2013, 68: 273-282.
[356] Parsons AB et al. ; Integration of chemical-genetic and genetic interaction data links bioactive compounds to cellular target pathways. Nat Biotechnol., 2004, 22(1): 62-69.

[357] Lopez A et al. ; Chemical-genetic approaches for exploring the mode of action of natural products. Progress in Drug Research., 2008, 66: 237-271.

[358] Manach C et al. ; Bioavailability and bioefficacy of polyphenols in humans. Review of 97 bioavailability studies. American Journal of Clinical Nutrition, 2005, 81(1Suppl.): 230S-242S.

[359] Carbonell-Capella JM et al. ; Analytical Methods for Determining Bioavailability and Bioaccessibility of Bioactive Compounds from Fruits and Vegetables: A Review. Comprehensive Reviews in Food Science and Food Safety. 2014, 13(2) : 155-171.

[360] Rein MJ et al. ; Bioavailability of bioactive food compounds: a challenging journey to bioefficacy. British Journal of Clinical Pharmacology, 2012, 75(3): 588-602.

[361] Traka MH and Mithen RF ; Plant Science and Human Nutrition: Challenges in Assessing Health-Promoting Properties of Phytochemicals. The Plant Cell, 2011, 23: 2483-2497.

[362] Gärtner C et al.; Lycopene is more bioavailable from tomato paste than from fresh tomatoes. American Journal of Clinical Nutrition, 1997, 66: 116-122.

[363] Giovannuccci E ; Tomatoes, tomato-based products, lycopene, and cancer: review of the epidemiologic literature. Journal of the National Cancer Institute., 1999, 91: 317-331.

[364] Arab L and Steck S ; Lycopene and cardiovascular disease. American Journal of Clinical Nutrition, 2000, 71: 1691S-1695S.

[365] Yang CS et al. ; Bioavailability issues in studying the health effects of plant polyphenolic compounds. Molecular Nutrition \& Food Research, 2008, 52(Suppl. 1): S139-S151.

[366] Liang XT and Fang WS ; Medicinal Chemistry of Bioactive Natural Products. John Wiley \& Sons, Inc., 2006: 460p.

[367] Borges F et al. ; Simple Coumarins and Analogues in Medicinal Chemistry: Occurrence, Synthesis and Biological Activity. Current Medicinal Chemistry, 2005, 12(8) : 887-916.

[368] Oey I et al. ; Does High Pressure Processing Influence Nutritional Aspects of Plant Based Food Systems? Trends in Food Science and Technology, 2008, 19: 300-308.

[369] Fang Z and Bhandari B ; Encapsulation of polyphenols - A review. Trends in Food Science and Technology, 2010, 21: $510-523$.

[370] Oehlke $\mathrm{K}$ et al. ; Potential bioavailability enhancement of bioactive compounds using food-grade engineered nanomaterials: a review of the existing evidence. Food \& Function, 2014, 5(7): 1341-1359.

[371] Shimoda K et al. ; Production of $\beta$-Maltooligosaccharides of $\alpha$ and $\delta$-Tocopherols by Klebsiella pneumoniae and Cyclodextrin Glucanotransferase as Anti-allergic Agents. Molecules, 2009, 14: 3106-3114.

[372] Larrick et al.; gamma-Tocopherol therapy for Restenosis Prevention. Patent Application Publication. United States, $2013: 13 p$. 
[373] Zvaigzne G. and Kārklina D ; Health Promoting Chemical Components of Orange Juice. Proceedings of the Latvian Academy of Sciences (Section B), 2013, 67(4-5): 329-333.
[374] Anonymous; La santé vient en mangeant : le guide alimentaire pour tous. Programme national nutrition-santé (PNNS), 2002: $130 \mathrm{p}$. 